\title{
Polyploidy in Industrial Crops: Applications and Perspectives in Plant Breeding
}

\author{
Anna Trojak-Goluch ${ }^{1, *}$, Magdalena Kawka-Lipińska ${ }^{1}$, Katarzyna Wielgusz ${ }^{2}$ (D) and Marcin Praczyk ${ }^{2}$ \\ 1 Institute of Soil Science and Plant Cultivation-State Research Institute, Czartoryskich 8, \\ 24-100 Puławy, Poland; Magdalena.Kawka@iung.pulawy.pl \\ 2 Institute of Natural Fibres and Medicinal Plants-National Research Institute, Wojska Polskiego 71 B, \\ 60-630 Poznań, Poland; katarzyna.wielgusz@iwnirz.pl (K.W.); marcin.praczyk@iwnirz.pl (M.P.) \\ * Correspondence: anngol@iung.pulawy.pl; Tel.: +48-81-4786-933
}

Citation: Trojak-Goluch, A.; Kawka-Lipińska, M.; Wielgusz, K.; Praczyk, M. Polyploidy in Industrial Crops: Applications and Perspectives in Plant Breeding. Agronomy 2021, 11, 2574. https://doi.org/10.3390/ agronomy11122574

Academic Editors: Othmane Merah and Salvatore Ceccarelli

Received: 16 October 2021

Accepted: 15 December 2021

Published: 17 December 2021

Publisher's Note: MDPI stays neutral with regard to jurisdictional claims in published maps and institutional affiliations.

Copyright: (c) 2021 by the authors. Licensee MDPI, Basel, Switzerland. This article is an open access article distributed under the terms and conditions of the Creative Commons Attribution (CC BY) license (https:/ / creativecommons.org/licenses/by/ $4.0 /)$.

\begin{abstract}
Polyploidisation is an important process in the evolution of many plant species. An additional set of chromosomes can be derived from intraspecific genome duplication (autopolyploidy) or hybridising divergent genomes and chromosome doubling (allopolyploidy). Special forms of polyploidy are autoallopolyploidy and segmental allopolyploidy. Polyploidy arises from two basic processes: spontaneously occurring disturbances of meiotic division and induced by antimitotic agents' disruption of mitosis. The first involves the induction and fusion of unreduced gametes, resulting in the formation of triploids and tetraploids. The second process uses antimitotics that disrupt cellular microtubules and prevent chromosome's sister chromatids motion during anaphase. Colchicine, oryzalin, and trifluralin are the most commonly used antimitotics for inducing polyploids in plants. The exposure time and concentration of the antimitotics and the species, cultivar, genotype, and tissue type affect the efficiency of genome duplication. Polyploids are distinguished from diploids by increased cell size and vegetative parts of plants and increased content of secondary metabolites. Genome duplication generates several changes at the epigenetic level resulting in altered gene expression. Polyploidisation is used in plant breeding to overcome the non-viability and infertility of interspecific hybrids, obtain seedless polyploid cultivars and increase resistance/tolerance to biotic and abiotic factors.
\end{abstract}

Keywords: antimitotic agents; chemical composition; morphology; polyploidisation; plant breeding; sexual reproduction

\section{Introduction}

Polyploidisation is an important phenomenon in plants and animals. One evolutionary mechanism promotes speciation, biodiversity, and adaptation to changing environmental conditions [1]. Interest in polyploidy has been recorded since the early 20th century when Winkler introduced the term of polyploid organisms [2]. Morphological features of polyploids such as plant height, size of leaves, flowers and pollen grains were determined [3-5]. It was estimated that about $95 \%$ of ferns, $15 \%$ of gymnosperms [6] and about $70 \%$ of angiosperms have experienced one or more episodes of chromosomes doubling in their evolutionary history [7]. In subsequent years, the development of molecular techniques such as karyotype analysis, genome sequencing, and protein electrophoresis allowed for studies that provided new data on the mechanisms of polyploid formation and their adaptation to new habitats. It was shown that many species, including Arabidopsis thaliana L. Heynh., Brassica napus L., are evolutionarily paleopolyploids, whose genomes contain several duplicated genes resulting from multiple rounds of polyploidisation followed by intensive structural and epigenetic transformations [8]. The division of polyploids into four basic types was also introduced: autopolyploids, allopolyploids, autoallopolyploids, and segmental allopolyploids [6]. Autopolyploids include organisms that have a multiplicated set of chromosomes from a single species [9]. The typical genome formula for defining an 
autopolyploid contains a single repeated letter (e.g., AAAA, BBBBBB). Autopolyploids during meiosis often form multivalents that may abnormally move to progeny cells, forming gametes with an unbalanced number of chromosomes. As a result, they are often sterile or produce gametes with reduced viability. Allopolyploids and autoallopolyploids are hybrids of more or less related species in which the chromosome number of the parental genomes has been duplicated [10]. Autoallopolyploids are formed by genome doubling following allopolyploid formation [11]. The simplest formula describing this group of polyploids is the notation $\mathrm{AABB}$, where the $\mathrm{A}$ genome is derived from one and the $\mathrm{B}$ genome from the other parental species. Economically important allopolyploids include Gossypium hirsutum L., Miscanthus $\times$ giganteus Greef et Deu., Nicotiana tabacum L., Saccharum officinarum L. and Arachis hypogaea L. [12-16]. The next described type are segmental allopolyploids, i.e., forms intermediate between allopolyploids and autopolyploids. In order to cover all types of polyploids obtained by hybridisation (allopolyploids, autoallopolyploids and segmental allopolyploids), the term amphiploids is used. It refers to hybrids containing two or more sets of chromosomes from each parent [11].

Polyploidy in natural populations is thought to arise from two basic processes. The first involves doubling the number of chromosomes in meristematic cells, zygote giving rise to new mixoploid or polyploid organisms. The second, in turn, is explained by the production of unreduced gametes by plants, which after fusion, enable the formation of fertile hybrids giving rise to auto- or allopolyploids [17]. The fusion of gametes from the same species conditions the formation of an autopolyploid, while the fusion of unreduced gametes from an interspecific hybrid gives rise to an allopolyploid. Production of unreduced gametes may be favoured by the mode of reproduction of diploid species, genetic conditions, and external factors such as the availability of new ecological niches, temperature, water stress, nutrient deficiency, and plant injury [18]. Crosses between races or cultivars of the same species usually result in segmental allopolyploids, which are characterised by the presence of homologous segments in chromosomes belonging to different genomes. Therefore, homologous chromosomes conjugate in meiosis, similar to diploids, allowing the production of functional gametes. In addition, there are chromosome changes accompanied by genomic exchanges and epigenetic modifications [19]. Examples of segmental allopolyploids are Solanum tuberosum L. and Prunus cerasus L. [20].

Plant genomes, unlike animal genomes, are very tolerant to increased DNA content. However, the consequences of polyploidy in different taxonomic units are sometimes diverse. In autopolyploids, the increased size of the somatic cells and increased content of cell sap are most commonly observed compared to diploids. These characteristics promote the expansion of vegetative parts of plants [21]. In the case of allopolyploids, the combination of genomes from different species, and thus genes that determine particular plant characteristics, favours the occurrence of heterosis effects [22]. Hence, natural allopolyploids generally exhibit greater colonisation capacity than their diploid counterparts and, as a result, extend the geographic range of species. Festuca appenina De Not. allopolyploids formed from a cross between F. pratensis Huds. and related fescue species inhabit parts of the Alps, Apennines and Carpathians, that are inaccessible to their parents [23]. The extreme genetic plasticity of allopolyploids also favours their increased tolerance to biotic and abiotic stresses. For example, $M$. $\times$ giganteus, obtained by hybridisation of $M$. sinensis Andersson and M. sacchariflorus Maxim., has s high biomass yield along with tolerance to cold stress [24]. Sometimes, however, polyploidisation of the genome can cause negative effects in the form of decreased plant viability and productivity [25]. Another frequently observed phenomenon, especially in autotetraploids, is disorders of chromosome pairing during meiosis and the formation of gametes with an unbalanced number of chromosomes, which contribute to decreased plant fertility and sometimes even sterility. However, autotetraploids have evolved mechanisms that allow regular chromosome segregation and often only modestly reduced fertility [10].

Work on plant genome multiplication and evaluation of polyploid forms has been the subject of many reports $[9,17,26]$. They provided a wealth of information on the 
mechanisms of polyploid formation and their role in plant evolution, origin, geographical distribution, amd morphological and physiological manifestations of polyploidy. The present study shows the methods of polyploid induction, the effect of polyploidy on the growth and morphological traits of plants, quantitative and qualitative modifications of primary and secondary metabolites induced by polyploids, and the importance of breeding and agricultural practice of polyploids of industrial plants that are widespread worldwide. Typical industrial species such as hop, cotton, hemp or miscanthus are discussed, but also those which, apart from their use in the food or pharmaceutical industry, are applied in other branches of fuel and energy, chemical, wood-paper and textile industries.

\section{Methods of Polyploid Induction}

There are several methods of polyploid formation in plants. Among the oldest and most important ways are polyploidisation associated with sexual reproduction and multiplication of chromosome complexes in somatic cells.

\subsection{Sexual Polyploidisation}

\subsubsection{Naturally Occurring Unreduced Gametes}

The formation of polyploids sexually is possible due to the spontaneous disruption of meiotic divisions and the production of gametes with an unreduced number of chromosomes (2n). A tetraploid organism is formed if sperm fertilises a $2 n$ gamete with an unreduced number of chromosomes $(2 n)$. Combining a $2 n$ gamete with sperm of a reduced number of chromosomes (n) will produce a triploid [17]. The polyploids thus obtained have a greater genetic variability than diploid organisms. They also show a wide spectrum of genetic plasticity resulting from increased gene expression and genetic robustness [27]. The development of unreduced gametes may be favoured by internal, genetic factors, among them the type of plant growth and the way of reproduction of the species [18]. In perennial plants, the formation of $2 \mathrm{n}$ gametes in the course of gametogenesis is much more frequent than in annual plants. Spontaneous polyploid pollen grains and naturally occurring triploid individuals have been observed in Acacia delbata L., Quercus petraea (Matt.), Quercus robur L. $[28,29]$. Similarly, polyploid gametes are much more common in self-pollinated plants than in self-incompatible plants [18]. Some genes can affect the course of meiosis and the formation of $2 \mathrm{n}$ gametes [30,31]. Such genes and the production of $2 \mathrm{n}$ egg cells have been demonstrated in diplosporic apomictic species Taraxacum officinale F.H. Wigg. [31]. Several non-redundant gametes are also produced in interspecific and intergeneric hybrids. Interspecific hybrids (amphihaploids) of N. glauca Grah. and N. langsdorfii Weinm., having a haploid set of chromosomes from each of the parents, regularly showed a relatively high percentage of unreduced gametes [14]. Amphihaploids of N. tabacum $\times$ N. glauca shows a failure of one of the meiotic divisions, leading to the formation of restitution nuclei and consequently the production of $2 \mathrm{n}$ male gametes [32]. Unreduced gametes have also been observed in interspecific hybrids of G. hirsutum $\times$ G. herbaceum L. [33] and Hibiscus syriacus L. $\times$ H. paramutabilis Bailey [34]. The presence of unreduced gametes overcomes infertility of $\mathrm{F}_{1}$ hybrids and allows obtaining polyploidy progenies.

\subsubsection{Induction of Unreduced Gametes and Artificial Hybridisation}

External factors favouring the formation of $2 n$ gametes may include heat shocks applied during meiosis, high irradiance, water or nutrient limitation $[18,35]$. The ability to form polyploid gametes as a result of heat shock is well known among poplars. The appearance of female $2 \mathrm{n}$ gametes due to high temperatures $\left(38-44^{\circ} \mathrm{C}\right)$ on Populus adenopoda Maximowicz was reported by Lu et al. [36]. An increased frequency of polyploid gametes was also noted in Populus pseudo-simonii Kitag. × P. nigra L. "Zheyin3\#" after the heat treatment of female buds [37]. Equally beneficial for increasing the production of unreduced gametes that are available for crossing is nitrous oxide $\left(\mathrm{N}_{2} \mathrm{O}\right)$. Amdahl et al. used this physical inactivator to induce tetraploids of Trifolium pratense L. [38]. 
Controlled interploid crosses can also induce polyploids $2 \mathrm{x} \times 2 \mathrm{x}, 2 \mathrm{x} \times 3 \mathrm{x}$. Kostoff obtained in 1938 a synthetic allopolyploid Nicotiana tabacum crossing the $F_{1}$ hybrids of $N$. sylvestris Speg. and Comes $(2 x) \times N$. tomentosiformis $\mathrm{L}$. $(2 \mathrm{x})$ with $N$. sylvestris, and then pollinating the resulting plants with pollen of $N$. tomentosiformis (2x) [39]. As a result of the hybridisation of the diploid parental forms $(2 x \times 2 x) N$. glutinosa L. and $N$. tabacum, a synthetic polyploid species $N$. digluta was obtained [40]. A widely used breeding method also crosses tetraploids with diploid individuals in an arrangement of $4 \mathrm{x} \times 2 \mathrm{x}$ and $2 \mathrm{x} \times 4 \mathrm{x}$. Haunold [41] crossed tetraploid hop forms with diploid individuals and obtained $76.3 \%$ of triploids $(2 \mathrm{n}=3 \mathrm{x}=30)$ as well as several aneuploids. A similar interploid crossing technique was used by Beatson and Brewer [42], resulting in many triploid hop cultivars. Beatson et al. further showed that in the progeny obtained by free pollination of triploid cultivars, $16.2 \%$ of the plants were tetraploids, $39.9 \%$ were triploids, and $0.7 \%$ were pentaploids [43]. Studies on diploids of Salix purpurea L. and tetraploids of S. miyabeana Seemen. hybridisation led to triploid genotypes with improved biomass yield [44]. As a result of artificial crosses between diploid $M$. sinensis and tetraploid M. sacchariflorus, triploid genotypes $M . \times$ giganteus were obtained [45]. This species is an important plant that produces the raw materials for biofuels and biomaterials in Europe and North America [46] (Table 1).

In the case of Echinacea purpurea, L. crossing was done in an arrangement of $2 x \times 3 x$ and $3 x \times 2 x$. When a triploid was used as a pollen donor, mainly aneuploids and a small number of diploids, tetraploids, and pentaploids were identified in the progeny [47]. In contrast, using a diploid as the male parent resulted in a significantly lower proportion of polyploids in the progeny. It suggested that the efficiency of polyploid induction in artificial hybridisation is dependent on the parent combination.

In controlled interploid crossing, embryo death is sometimes observed at an early stage of development. It is usually a result of endosperm degeneration during the initial stages of embryogenesis and the associated seed abortion [48]. One of the ways of overcoming the barriers of seed non-viability is the culture of isolated embryos. This method has been used, among others, to rescue embryos of Cannabis sativa L. derived from seeds obtained from crossing a tetraploid and diploid form of "Wife" [49]. By using embryo cultures, Touchell and Ranney [50] obtained unique interploid interspecific hybrids $(6 x \times 2 x)$ M. giganteus $\times$ M. sinensis. The authors pointed out that the culture of isolated embryos provides an excellent way to multiply the genome by interploidy hybridisation. However, the method's effectiveness depends on the species/genotypes used for crosses, the number of days after pollination, and the in vitro culture conditions, i.e., medium composition, temperature and light.

Table 1. Selected industrial plants and their characterisation regarding their commercial interest, ploidy, origin/formation process.

\begin{tabular}{|c|c|c|c|c|c|}
\hline Species & Common Name & $\begin{array}{l}\text { Commercial } \\
\text { Interest }\end{array}$ & $\begin{array}{l}\text { Ploidy and } \\
\text { Chromosome } \\
\text { Number }\end{array}$ & $\begin{array}{l}\text { Origin/Formation } \\
\text { Process }\end{array}$ & References \\
\hline Gossypium hirsutum L. & Cotton & Industrial & $2 n=4 x^{2}=52$ & Natural/allopolyploid & [33] \\
\hline Gossypium barbadense L. & Egyptian cotton & Industrial & $2 n=4 x=52$ & Natural/allopolyploid & [51] \\
\hline $\begin{array}{l}\text { Miscantus } \times \text { giganteus } \\
\text { Greef et Deu. }\end{array}$ & Miscanthus & Industrial & $2 n=3 x^{1}=57$ & $\begin{array}{c}\text { Natural/Synthetic/ } \\
\text { allopolyploid }\end{array}$ & [52] \\
\hline $\begin{array}{l}\text { M. sacchariflorus } \\
\text { (Maxim.) Hack. }\end{array}$ & Miscanthus & Industrial & $2 n=4 x=76$ & Natural/allopolyploid & [53] \\
\hline Nicotiana tabacum L. & Tobacco & Industrial & $2 n=4 x=48$ & Natural/allopolyploid & [39] \\
\hline Nicotiana digluta & - & Industrial & $2 n=4 x=72$ & Synthetic/allopolyploid & {$[40]$} \\
\hline Saccharum officinarum L. & Sugarcane & Industrial & $2 n=8 x^{4}=80$ & Natural/allopolyploid & [15] \\
\hline Beta vulgaris L. & Beet & Industrial & $2 n=3 x=27$ & Synthetic/autopolyploid & {$[54]$} \\
\hline
\end{tabular}


Table 1. Cont.

\begin{tabular}{|c|c|c|c|c|c|}
\hline Species & Common Name & $\begin{array}{l}\text { Commercial } \\
\text { Interest }\end{array}$ & $\begin{array}{c}\text { Ploidy and } \\
\text { Chromosome } \\
\text { Number }\end{array}$ & $\begin{array}{c}\text { Origin/Formation } \\
\text { Process }\end{array}$ & References \\
\hline Agava sisalana Perrine & Sisal hemp & Industrial & $2 n=5 x^{3}=150$ & Natural/allopolyploid & [55] \\
\hline Festuca apennina De Not. & Fescue & Forage & $2 n=4 x=28$ & Natural/allopolyploid & {$[23]$} \\
\hline Hybiscus syriacus L. & Althea & Ornamental & $2 n=4 x=80$ & Natural/autopolyploid & {$[56]$} \\
\hline
\end{tabular}

\subsection{Somatic Polyploidisation}

Polyploidy in somatic cells can be induced by the disruption of chromosome disjunction at anaphase of mitosis. Several stress factors such as temperature shock, plant injury, or X-irradiation are used for this purpose [57]. The best results are obtained by applying very high or very low temperatures at the initial embryogenesis stage during the zygote's first divisions. Wang et al. obtained chromosome doubling of (Populus pseudo-simonii $\times$ P. nigra "Zheyin3\#" $) \times(P . \times$ beijingensis W.Y. Hsu $)$ due to high-temperature treatment during the embryo sac development [58]. Similarly, Guo et al. conducted a study in which zygotic embryo chromosome doubling was induced using high temperatures to produce triploids and tetraploids in P. simonii [59].

The most commonly used method of multiplying the number of chromosomes in somatic cells of crop plants, is mitotic polyploidisation using chemicals that interfere with the course of mitosis in plant somatic cells. The most effective and widely used antimitotic is colchicine $\mathrm{C}_{22} \mathrm{H}_{25} \mathrm{NO}_{6}$, an alkaloid extracted from the seeds and roots of autumn/winter fruit (Colchicum autumnale L.). It dissolves well in alcohol and chloroform, less well in water and glycerol. Its action disrupts the function of microtubules responsible for the propagation of chromosomes to daughter cells, leading to the formation of polyploid nuclei [60]. In addition to its specific action on the chromosomal apparatus, it also acts directly on cells causing them to grow in width. Colchicine in higher concentrations is very toxic for animals and plants, so when using it, low doses with prolonged exposure time are recommended [60]. In plant research, colchicine was first used in 1937 by Dustin and colleagues, who treated germinating seeds and shoot tips of wheat with it. Since then, several methods have been developed for its application to many plant species, including industrial crops (Table 2). Another chemical compound is a member of the dinitroaniline class-oryzalin, that acts through the disruption (depolymerisation) of microtubules, thus blocking the anisotropic growth of plant cells [61]. Petersen et al. treated plants growing in the soil and in vitro shoots, embryogenic callus, shoot apices, and leaf explants of $M$. sinensis with different concentrations of colchicine and oryzalin for different concentrations and exposure time [62]. They found that the treatment of leaf explants with oryzalin was the most efficient system in tetraploid production.

Similarly, Talebi et al. showed that in the case of Agastache foeniculum Gronov. seeds, treatment with oryzalin is a more effective technique for tetraploid induction than the use of colchicine [63]. Other antimitotic agents rarely used in the polyploidisation of industrial plants are trifluralin and amiprophos-methyl $[64,65]$.

The issue of plant polyploid induction has been addressed many times in world literature $[9,17,26]$. Presented experimental data indicate that the efficiency of polyploid induction using antimitotic agents depends on many factors, the most important of which are the type of plant tissue, the genotype of the donor plant, method of antimitotic application and plant growth conditions [17].

\subsubsection{Type of Plant Tissue}

A frequently used method for polyploid induction is soaking seeds in aqueous solutions of mitotic inhibitors. Seeds of five $C$. sativa cultivars were treated with $0.05 \%$ colchicine for $12 \mathrm{~h}$, yielding a $26-64 \%$ tetraploid induction rate [49]. Equally high genome doubling 
efficiency was obtained for Nicotiana alata J. Link and C. Otto and Eucommia ulmoides Oliver by soaking the seeds in a $0.5 \%$ colchicine solution for $48 \mathrm{~h}[66,67]$. Dhamayanthi and Gotmare [68] treated seeds as well as seedlings and stem cuttings with colchicine to induce tetraploids of Gossypium armourianum Kearney and G. aridum Rose and Standley and found that seeds are the most suitable plant material in inducing polyploidy. Luo et al. soaked seeds of Taraxacum kok-saghyz Rodin. in four colchicine solutions $(0.05,0.1$, $0.2,0.5 \%)$ for $12,24,48,72$ and $96 \mathrm{~h}$ [69]. The authors report that the tetraploid induction rate (\%) increased with increasing colchicine concentrations; however, high doses of the antimitotic agent drastically reduced the survival rate. Treatment of seeds with a moderate concentration of colchicine $(0.2 \%)$ for a short time $(24 \mathrm{~h})$ proved to be the most effective way to obtain the highest induction rate of polyploids (4.92\%). For many industrial species, satisfactory results of polyploid induction are also obtained as a result of antimitotic treatment of seedlings containing intensely dividing meristematic tissues. The treatment of apices of seedlings with a colchicine-soaked cotton swab allowed obtaining from 2.5 to $10 \%$ tetraploids of Jatropha curcas L. [5]. In Gossypium arboreum L, we obtained 4.0 to $42.31 \%$ of polyploids when colchicine solutions solidified with agar were applied to the seedlings' tips [70].

In contrast, Głowacka et al. immersed young plants of $M$. sinensis and $M . \times$ giganteus in aqueous colchicine solutions (626 and $1252 \mu \mathrm{M})$ for $6,18,24 \mathrm{~h}$ [71]. In order to increase tissue penetration by chemical agents, colchicine solution was supplemented with 1 or $2 \%$ DMSO (dimethyl sulfoxide) and Tween 20. The authors obtained 50 tetraploids (4x) and 2 hexaploids (6x); however, the addition of surfactants to the colchicine solution reduced the survival rate. Haunold et al., on the other hand, demonstrated that shoots of older plants could be used for the induction of hop polyploids using colchicine. However, their treatment with colchicine solution often results in the appearance of mixoploid plants [41]. 
Table 2. Polyploid induction of industrial plants using various plant materials, antimitotic agents, concentration and exposure times.

\begin{tabular}{|c|c|c|c|c|c|}
\hline Species & Plant Material & Treatment & Exposure & $\begin{array}{c}\text { Polyploid Frequency/Most Successful } \\
\text { Treatment }\end{array}$ & References \\
\hline $\begin{array}{l}\text { Gossypium armourianum Kearne) } \\
\text { G. aridum (Rose and Standl.) Skovst. }\end{array}$ & Seeds & Colchicine $0.5,0.7,0.9,1.0,1.5 \%$ & $4,8,12,16,20,24 \mathrm{~h}$ & $\begin{array}{c}4 \mathrm{x}^{1}=71.4 \% \text { for G. armourianum } 4 \mathrm{x}=83.5 \% \text { for } \\
\text { G. aridum / colchicine } 0.9 \%, 20 \mathrm{~h}\end{array}$ & [68] \\
\hline Gossypium herbaceum L. & Seeds & Colchicine $0.2,0.4,0.6,0.9 \%$ & $4 \mathrm{~h}$ & colchicine $0.2 \%$ & {$[72]$} \\
\hline Taraxacum kok-saghyz Rodin. & Seeds & $\begin{array}{c}\text { Colchicine } 0.05,0.1,0.2,0.5 \%+ \\
\text { 1\% DMSO }\end{array}$ & $12,24,48,72,96 \mathrm{~h}$ & $4 \mathrm{x}=1.49-4.92 \% /$ colchicine $0.2 \%, 24 \mathrm{~h}$ & [69] \\
\hline Nicotiana alata Link and Otto & Seeds & Colchicine $0.1,0.25,0.5 \%$ & $12,24,48 \mathrm{~h}$ & $4 \mathrm{x}=\mathrm{NI} /$ colchicine $0.5 \%, 48 \mathrm{~h}$ & [66] \\
\hline Eucommia ulmoides Oliver & Seeds & Colchicine $0.1,0.5 \%$ & $24,48,72 \mathrm{~h}$ & $\begin{array}{c}4 \mathrm{x}=4 / 48 *-9 / 18(8.3-50 \%) / \text { colchicine } 0.5 \% \\
48 \mathrm{~h}\end{array}$ & [67] \\
\hline \multirow{3}{*}{ Agastache foeniculum Gronov. } & \multirow{3}{*}{ Seeds } & $\begin{array}{l}\text { Colchicine 5000, 12,500, } 17,500 \\
\mu \mathrm{M}+\text { Tween } 20\end{array}$ & \multirow{3}{*}{$6,12,24 \mathrm{~h}$} & $4 \mathrm{x}=4 \% /$ colchicine $17,500 \mu \mathrm{M}, 24 \mathrm{~h}$ & \multirow{3}{*}[63]{} \\
\hline & & Oryzalin $10,50,100 \mu \mathrm{M}$ & & $4 \mathrm{x}=4.0-20.0 \%$ /oryzalin $100 \mu \mathrm{M}, 24 \mathrm{~h}$ & \\
\hline & & Trifuralin $10,50,100 \mu \mathrm{M}$ & & $4 \mathrm{x}=2.0-14.0 \% /$ trifluralin $50 \mu \mathrm{M}, 24 \mathrm{~h}$ & \\
\hline Cannabis sativa L. var. sativa & Pregerminated seeds & Colchicine $0.05 \%$ & $12 \mathrm{~h}$ & $\begin{array}{c}4 \mathrm{x}=5 / 19 \text { for "Abacus" } \mathrm{x} \text { "Wife", 14/22 for } \\
\text { "Youngsim10"; } \\
2 \mathrm{x} / 4 \mathrm{x}^{5}=1 / 18 \text { for "Mountain Mango", } 4 / 19 \\
\text { for "Wife" }\end{array}$ & [49] \\
\hline Jatropha curcas L. & Seedling tips & $\begin{array}{l}\text { Colchicine } 0.1,0.2,0.4,0.6,0.8 \% \\
+ \text { DMSO, } 3 x \text { per day }\end{array}$ & $1,4,7,10 \mathrm{~d}$ & $4 x, 8 x, 4 x / 8 x^{5}=2.5-15 \% /$ colchicine $0.1 \%, 7 d$ & [5] \\
\hline Gossypium arboreum $\mathrm{L}$. & Seedling tips & $\begin{array}{l}1 \% \text { agar }+ \text { colchicine } 0.1,0.2 \\
0.3,0.4 \%\end{array}$ & $24 \mathrm{~h}$ & $4 \mathrm{x}=4.0-42.31 \% /$ colchicine $0.1 \%$ & {$[70]$} \\
\hline Humulus lupulus L. & Shoot tips & $\begin{array}{l}\text { Liquid colchicine } 0.01,0.05 \\
0.1 \%\end{array}$ & $24,48,72 \mathrm{~h}$ & $\begin{array}{c}4 \mathrm{x}=5.6-25 \% / \text { colchicine } 0.05 \%, 48 \mathrm{~h} ; 2 \mathrm{x} / 4 \mathrm{x}= \\
11.1-52.8 \%\end{array}$ & [73] \\
\hline C. sativa $\mathrm{L}$. & Axillary buds & $\begin{array}{c}\text { Liquid MS }+ \text { oryzalin } 20,40,60 \\
\mu \mathrm{M}\end{array}$ & $24 \mathrm{~h}$ & $\begin{array}{c}4 \mathrm{x}=50.0-100 \% / \text { oryzalin } 40 \mu \mathrm{M} \text { for Strain } 1,60 \\
\mu \mathrm{M} \text { for Strain } 2\end{array}$ & [74] \\
\hline Salix viminalis $\mathrm{L}$. & Axillary buds & Sterile colchicine $0.05 \%, 0.1 \%$ & $48 \mathrm{~h}$ & $4 \mathrm{x}=16$ lines $/ \mathrm{NI}$ & [75] \\
\hline Echinacea purpurea L. & Petiole explants & $\begin{array}{l}\text { Solid MS + colchicine } 30,60 \\
120,240 \mathrm{mg} / \mathrm{L}\end{array}$ & $30 \mathrm{~d}$ & $\begin{array}{c}4 \mathrm{x}=3 / 51-11 / 51(5.9-21.6 \%) / \text { colchicine } 120 \\
\mathrm{mg} / \mathrm{L} ; 2 \mathrm{x} / 4 \mathrm{x}=2 / 51-6 / 51\end{array}$ & [76] \\
\hline Populus alba $\times$ P. glandulosa & Leaf explants & Colchicine $(40,50,60 \mathrm{mg} / \mathrm{L})$ & $2,3,4 \mathrm{~d}$ & $4 \mathrm{x}=2.17-37.03 \% /$ colchicine $50 \mathrm{mg} / \mathrm{L}, 3 \mathrm{~d}$ & [77] \\
\hline H. lupulus L. & Nodal segments & solid MS + oryzalin $1,5,10 \mu \mathrm{M}$ & $14 \mathrm{~d}$ & $4 \mathrm{x}=1 / 14-7 / 10 /$ oryzalin $10 \mu \mathrm{M}$ & [78] \\
\hline
\end{tabular}


Table 2. Cont.

\begin{tabular}{|c|c|c|c|c|c|}
\hline Species & Plant Material & Treatment & Exposure & $\begin{array}{c}\text { Polyploid Frequency/Most Successful } \\
\text { Treatment }\end{array}$ & References \\
\hline \multirow{2}{*}{ Thymus vulgaris L. } & \multirow{2}{*}{ Nodal segments } & $\begin{array}{c}\text { Solid MS + oryzalin } 0.346,1.73 \\
3.46 \mathrm{mg} / \mathrm{L}\end{array}$ & $14 \mathrm{~d}$ & $4 \mathrm{x}=15.8-66.7 \% /$ oryzalin $1.73 \mathrm{mg} / \mathrm{L}$ & \multirow{2}{*}[79]{} \\
\hline & & $\begin{array}{c}\text { oryzalin } 1.73,3.46,5.19,6.92 \\
8.65 \mathrm{mg} / \mathrm{L}\end{array}$ & $24 \mathrm{~h}$ & $4 \mathrm{x}=7.1-25 \% /$ oryzalin $3.46 \mathrm{mg} / \mathrm{L}$ & \\
\hline Lippia integrifolia (Gris) Hier. & Nodal segments & $\begin{array}{l}\text { Solid medium }+ \text { colchicine } \\
0.01 \%\end{array}$ & $15 \mathrm{~d}$ & $4 x=19 / 37(51.4 \%)$ & {$[80]$} \\
\hline Panax ginseng Mayer & roots & $\begin{array}{l}\text { Liquid MS + colchicine 50, } 100 \\
\text { mg/L }\end{array}$ & $12,24,36,48,60 \mathrm{~h}$ & $8 x^{4}=39$ lines, $6 x^{3}=1$ line $/ N I$ & {$[81]$} \\
\hline Miscantus $\times$ giganteus Greef et Deu. & \multirow{2}{*}{$\begin{array}{c}\text { Immature } \\
\text { inflorescence-derived } \\
\text { calli }\end{array}$} & Liquid MS + oryzalin $10 \mu \mathrm{M}$ & $36 \mathrm{~h}$ & $5 x^{2}$ and $6 x=30.4 \%$ & \multirow{2}{*}[52]{} \\
\hline Miscantus sinensis Anderss. & & Liquid MS + oryzalin $10 \mu \mathrm{M}$ & $36 \mathrm{~h}$ & $4 x=44.9 \%$ & \\
\hline Paulownia tomentosa Thunb. & Embryogenic callus & $\begin{array}{l}\text { Liquid MS + colchicine } 0.01 \\
0.05,0.1 \%\end{array}$ & $24,48,72 \mathrm{~h}$ & $4 \mathrm{x}=7.1-40.0 \% /$ colchicine $0.05 \%, 48 \mathrm{~h}$ & [82] \\
\hline Hevea brasilensis Müll.Arg. & $\begin{array}{c}\text { Immature } \\
\text { inflorescence-derived } \\
\text { calli }\end{array}$ & Colchicine $0.25-2.5 \mu \mathrm{M}$ & $2-24 \mathrm{~h}$ & $4 \mathrm{x}=0 / \mathrm{NI}$ & {$[83]$} \\
\hline
\end{tabular}

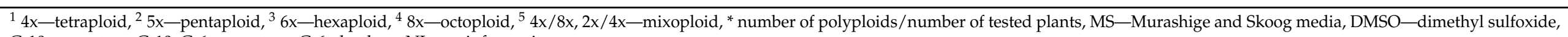
G-10-genotype G-10, G-6-genotype G-6, d-days, NI-no information. 
Techniques of in vitro plant polyploidisation have also been improved for many years. They make it possible to shorten the time of polyploid induction and increase the efficiency of this process because it takes place under controlled conditions. The first attempts to induce tobacco polyploids in vitro were made by Murashige and Nakano in the late 1960s [84]. As a result of the culture of pith stem fragments, they produced tetraploid plants. In the following years, Heinz and Mee [85] treated cell suspension with colchicine and produced polyploids of $S$. officinarum. Nowadays, the most commonly used plant material for in vitro polyploid induction are shoot tips, axillary buds, petiole or leaf explants, nodal segments, roots and callus $[74,77,78,81]$. A technique for the induction of tetraploid Humulus lupulus L. from apical meristems incubated in colchicine solution and shaken at $100 \mathrm{rpm}$ has been developed [73]. In C. sativa, many polyploids were regenerated from axillary buds treated with oryzalin or colchicine [74]. Chae et al. treated immature inflorescence-derived calli of $M . \times$ giganteus with oryzalin and developed pentaploid and hexaploid plants [52]. Also, Tang et al., treating embryogenic callus with liquid MS and colchicine, obtained 16 tetraploids of Paulownia tomentosa Steud., which constituted 13.3\% of total regenerants [82]. Also, in the case of $H$. brasilensis, tetraploid plants were obtained by culture of immature-derived embryogenic callus [83].

Recently, an efficient technique for obtaining polyploids of Thymus vulgaris L. has also been developed. It involves a 2-week culture of nodal fragments on MS medium with the addition of oryzalin. The number of polyploids obtained this way represented 10.3 to $66.7 \%$ of the regenerants [79]. The study by Švécarová et al. showed that for H. lupulus, it is possible to obtain a greater number of polyploids ( $70 \%$ of all tested) using this method [78]. An important issue related to plant regeneration from somatic tissues is the emerging somaclonal variability, resulting from the genetic variation of the primary explant (occurrence of cells with different ploidy), mutations in the genome or epigenetic changes. The frequency of its occurrence is largely related to the plant species. There are species susceptible to somaclonal variation, such as N. tabacum and S. officinarum. Also, fragments of older, differentiated tissues (e.g., from the stem), as well as callus cultures, are more prone to alterations (occurrence of polyploid or aneuploid cells); therefore, they are often used to obtain doubled haploids or tetraploids, e.g., tobacco [86]. Plants obtained both under in vivo and in vitro conditions, must therefore be tested for their degree of ploidy. Currently, a rapid and reliable measurement of genomic DNA content using a flow cytometer is used for this purpose [72]. The ploidy level of plants can also be assessed by the number of chromosomes in the somatic cells. This method is time-consuming; however, unlike flow cytometry, it can separate euploids from aneuploids [87]. Ploidy can also be determined by indirect methods based on evaluating morphological traits of plants correlated with the degree of ploidy. The most frequently evaluated traits include plant height, leaf size, stomata size and the number of chloroplasts per stomata [82,88-90].

\subsubsection{Genotype Dependent Polyploidisation}

In many industrial plant species, genome duplication efficiency is also significantly affected by the genotype of the donor plant. This relationship was observed after colchicine of germinated seeds of five cultivars of C. sativa. In the study, tetraploid induction frequency ranged from $26 \%$ to $64 \%$ for "Abacus" $\times$ "Wife" and "Youngsim 10 ", respectively [49]. Studies on polyploidisation of $C$. sativa with the method of axillary buds' treatment with oryzalin in liquid MS medium confirmed that the genotype (or in this case, a strain) of donor plant has a crucial effect on tetraploid frequency. Maru et al. treated seeds of six genotypes of G. herbaceum with different colchicine solutions, and showed that the G Cot23 genotype was distinguished by significantly greater ability to duplicate genetic material than the genotypes named G Cot21, G Cot25, ALF-1027, V-797, whereas, for genotype 4011, no tetraploids could be obtained [72]. A close relationship between the genotype of parent plants and the efficiency of polyploidisation was also observed in M. sinensis [71]. Ms21 genotype had almost five times higher polyploidisation rate than Ms16 genotype. Also, Śvécarová et al. demonstrated that among the four tested genotypes of H. lupulus, 
one (maple No. 72) was distinguished by a significantly higher frequency of polyploid induction, regardless of oryzalin concentration and application method [78]. Differences in genome polyploidisation efficiency depending on the genotype of the donor plant were also confirmed by studies on S. viminalis [75].

\subsubsection{Concentration of Antimitotic Agent and Exposure Time}

For most industrial plant species, the use of mutagenic compounds is essential for genome polyploidisation. Under in vivo conditions, the most commonly used are water solutions of antimitotic agents, in which biological material (seeds, seedlings, shoot tips, organs containing actively dividing cells) is immersed for several several dozen hours, after which the plant material is washed with water and transferred to a growth medium (most often peat substrate or perlite). Sometimes, especially when the mutagenic solution is applied pointwise, e.g., on older plant stems, lateral or apical buds, it is advantageous to use the antimitotic-soaked cotton plug method [5]. The efficiency of chemicals penetration into plant tissues and cells can be increased by adding surfactants (lanoline, Tween 20). Talebi et al. added Tween 20 to an antimitotic solution to increase the efficiency of polyploid induction from seeds of $A$. foeniculum [63]. In multicellular tissues, penetration of antimitotic agents is facilitated by sulfoxides such as dimethyl sulfoxide [91]. DMSO is an excellent solvent of polar and non-polar substances; additionally, it increases cell membrane permeability. The treatment of plant material also exerts a positive influence, especially shoot tips with semi-solid antimitotic stock (1\% agar) [70]. Under in vitro conditions, however, aqueous solutions of antimitotic agents are usually added to the liquid or agar-solidified growth media $[79,80,83]$. After a certain time of antimitotic action, the plant culture is transferred to a fresh medium in order to root or regenerate plants. It is important to use such doses of chemical agents to allow the survival of mutant cells and the regeneration of polyploids. High concentrations are toxic for plant cells and usually cause abnormal plant growth or reduced viability, while low concentrations may be ineffective or induce many mixoploids or aneuploids [60]. When determining the dosage, one must also take into account the possibility of a higher, compared to in vivo conditions, penetration of chemicals into mostly unprotected cells. In addition, some components of the media, such as sucrose or plant growth regulators, can interact with antimitotic agents and cause an increase or decrease in their effectiveness [92]. In the callus culture of $M . \times$ giganteus, the presence of additional substances negatively affected genome polyploidisation. The addition of Tween 20 and DMSO induced a significant reduction in plants surviving and in plants tillering [71].

Evaluation of the efficiency of obtaining polyploids of industrial plants depending on the concentration and time of antimitotic treatment has been the subject of many literature reports. Niu et al. reported that in J. curcas, soaking the seeds in a $0.1 \%$ colchicine solution for $24 \mathrm{~h}$ did not induce polyploids, while extending the exposure time to 4-7 days increased the polyploid induction rate from 10 to $15 \%$, respectively [5]. T. kok-saghyz seeds were subjected to $0.05-0.5 \%$ colchicine solutions for $12-96 \mathrm{~h}$, yielding a $1.49-4.92 \%$ induction efficiency [69]. In callus cultures of $M . \times$ giganteus, conducted on a medium containing colchicine $(313 \mu \mathrm{M})$, an increase in the proportion of polyploids was observed due to prolonged exposure from 2 to 4 days [13]. A colchicine concentration-dependent increase in ploidy level of G. armourianum, G. aridum and H. lupulus was observed [68,73]. Talebi et al. indicated that the concentration and exposure duration of oryzalin significantly affected the polyploid induction of A. foeniculum [63]. Also, concentration and time of exposure to oryzalin were significant factors in producing Bixa orellana L. polyploids [93].

\section{Effects of Polyploidisation on Morphological and Physiological Changes in Plants}

Polyploidisation can induce several modifications in plant cells, leading to changes in plant anatomical structure. An increase in the cell size plays a key role in physiological and developmental changes in plants by reducing the surface area to volume ratio [21] and usually manifests with the most noticeable polyploidisation effect referred to as the 
so-called "gigas" effect. This effect causes a change in the phenotype of plants. Cell size, nucleus volume, and cell cycle length belong to a set of so-called "nucleotypic" traits defined as phenotypic characteristics influenced by the large amount of DNA produced by polyploidisation rather than by the genes themselves [21]. The volume of tetraploid cells is approximately twice as large as the cells of their diploid parent forms, while the cell area is 1.5 times larger [94]. An increase in cell size does not always lead to an increase in the size of the whole plant, as the sheer number of cell divisions in polyploids is generally lower [25]. Nor does an increase in organ size always result in an increase in the overall biomass. The relationship between ploidy level and changes in phenotype depends on the plant species. For example, tetraploids E. ulmoides have a lower tendency to increase cell size, thereby increasing its biomass compared to other species. This is probably related to the silencing of certain duplicated genes [67]. An equally interesting example is octoploid J. curcas, whose leaves are much smaller than those of diploids, while the leaf cells of octoploids are larger [5].

Over the past century, one of the major goals of industrial plant breeding programs has been to obtain improved varieties using the phenomenon of induced polyploidy. Synthetic polyploids obtained in the laboratory are characterised by the fact that their phenotypes are not long adaptations of the products but are an organism's immediate reaction to the doubling of the genome [2]. Changes in the ploidy levels affect the morphological, physiological traits, and chemical composition of plants. Induced autopolyploids tend to have better morphological characteristics, producing larger tubers, rhizomes, and roots than diploids [95]. They are characterised by larger leaves, flowers and seeds, better photosynthetic properties, and increased biomass production than diploids [96]. This is particularly important for vegetatively propagated plants, whose yield is vegetative organs and those from which important secondary metabolites are obtained. Besides showing an increased gene activity, polyploids have reduced transpiration and better photosynthetic properties [97]. They sometimes exhibit delayed flowering, but with this prolonged time they have slower growth, greater tolerance to nutrient and mineral deficiencies, greater resistance to biotic and abiotic factors, and better adaptation to habitat conditions [98]. Slower polyploid growth is associated with increased DNA content and thus larger cell size. Larger cells require more time to replicate, which increases the duration of the cell cycle. As a result, this causes delays in the completion of apical meristem growth, resulting in a prolonged vegetative phase, which in turn causes delayed flowering of plants [25].

Induced autopolyploids are derived from a whole-genome duplication event of the same ancestral chromosome set. This means that chromosome duplication does not introduce additional new genetic material, but only increases the number of genes and chromosomes already present. Polyploids are less stable than diploids. Changes may occur in the genome at the structural level (genome rearrangements such as DNA deletion, meiotic/mitotic defects, aberrant recombination, transposable element activation TE), in the size of the genome (transposon insertion, satellite repeats amplification, deletion, illegitimate recombination), epigenetic changes such as changes in gene expression, modifications in the level of chromatin density through methylation or demethylation, modifications to histones, genetic changes (gene loss, gene subfunctionalisation, homoeolog expression bias) [99]. Their occurrence may explain why doubling the so-called genetic dose does not give a linear relationship between the increase in genetic material and the production of secondary metabolites.

Morphological and anatomical changes such as size and density of stomata, number of leaves, shoots, roots, flowers, leaf length/width ratio and shape, flower size, seed and pollen size, cell wall structure, plant height, plant habit, etc., are among the frequently observed changes caused by ploidy modification in plants (Table 3). The stomata of polyploid plants are usually larger than those of diploids, but there are far fewer per unit area. Also, the density of stomata can be considered an important indicator of the level of ploidy in plants [100]. 
Table 3. The effect of polyploidisation on morphological traits of selected industrial plants.

\begin{tabular}{|c|c|c|c|}
\hline Species & Morphological Traits & Ploidy & References \\
\hline \multirow{3}{*}{ Cannabis sativa L. } & $\begin{array}{l}\text { Shorter plants; larger stomata cells, guard cells and male flowers; } \\
\text { thicker xylem tissue, fewer primary and secondary fibre; lower leaf } \\
\text { index; decrease in the density of stomata cells and trichomes }\end{array}$ & $2 \mathrm{n}=4 \mathrm{x}$ & {$[49,101]$} \\
\hline & Intermediate stomata size between $2 x^{1}$ and $4 x^{3}$ & $2 n=3 x$ & [49] \\
\hline & $\begin{array}{l}\text { Larger stomata by about } 30 \% \text { and decrease in their density; larger } \\
\text { leaves; increase in trichome density by about } 40 \%\end{array}$ & $2 n=4 x$ & [74] \\
\hline \multirow{2}{*}{ Eucommia ulmoides Oliver } & Larger stomata and guard cells; decrease in density of stomata & $2 n=4 x$ & \multirow{2}{*}[67]{} \\
\hline & Smaller leaves; no flower buds & $2 n=8 x$ & \\
\hline \multirow{4}{*}{ Humulus lupulus L. } & $\begin{array}{l}\text { Thinner and shorter shoots; shorter internodes; smaller flowers and } \\
\text { leaves; larger lupuline glands; increase in cone weight; more } \\
\text { compact plant habit }\end{array}$ & $2 n=4 x$ & [73] \\
\hline & Larger stomata cells & $2 n=4 x$ & [88] \\
\hline & $\begin{array}{l}\text { Shorter internodes; larger, dark green leaves; slower root growth; } \\
\text { altered leaf shape; larger stomata cells }\end{array}$ & $2 \mathrm{n}=4 \mathrm{x}$ & [78] \\
\hline & $\begin{array}{l}\text { Seedless cones; higher shoot twist index; longer fructiferous } \\
\text { branches, internodes and cones; looser plant habit }\end{array}$ & $2 n=3 x^{2}$ & [102] \\
\hline \multirow[t]{2}{*}{ Jatropha curcas L. } & $\begin{array}{c}\text { Larger leaves, flowers, pollen grains, fruits, seeds; lower seed } \\
\text { weight; larger stomata cells; lower stomata density; fewer flowers, } \\
\text { fruits, seeds }\end{array}$ & $2 \mathrm{n}=4 \mathrm{x}$ & \multirow[t]{2}{*}{ [5] } \\
\hline & Shorter plants; smaller leaves; no flower buds & $2 n=8 x^{5}$ & \\
\hline Matricaria chamomilla L & $\begin{array}{l}\text { Taller plants; larger and heavier inflorescences; higher dry seed } \\
\text { weight }\end{array}$ & $2 \mathrm{n}=4 \mathrm{x}$ & [3] \\
\hline $\begin{array}{l}\text { Lavandula angustifolia subsp. } \\
\text { angustifolia Mill. }\end{array}$ & $\begin{array}{l}\text { Larger flowers, seeds, trichomes, guard cells; larger and thicker } \\
\text { leaves; thicker peduncles }\end{array}$ & $2 \mathrm{n}=4 \mathrm{x}$ & [4] \\
\hline $\begin{array}{l}\text { Miscanthus sacchariflorus } \\
\text { Maxim. }\end{array}$ & Larger stem diameter and stomata cells; fewer tillers & $2 n=4 x$ & [52] \\
\hline \multirow[b]{2}{*}{ Miscanthus sinensis Anderss. } & Two genotypes had broader leaves and larger stem diameter & $2 n=4 x$ & [13] \\
\hline & $\begin{array}{l}\text { Larger stem diameter and stomata cells; significantly fewer tillers; } \\
\text { shorter plants }\end{array}$ & $2 \mathrm{n}=4 \mathrm{x}$ & [52] \\
\hline \multirow{2}{*}{$\begin{array}{c}\text { Miscanthus } \times \text { giganteus Greef } \\
\text { et Deu. }\end{array}$} & One genotype had narrower leaves and a larger stem diameter & $2 n=6 x^{4}$ & [13] \\
\hline & Larger stem diameter and stomata cells; fewer tillers; shorter plants & $2 n=6 x$ & [52] \\
\hline $\begin{array}{l}\text { Paulownia tomentosa (Thunb.) } \\
\text { Steud }\end{array}$ & $\begin{array}{l}\text { Round leaves with serrate margins; larger stomata cells; decrease in } \\
\text { density of stomata cells; more chloroplasts }\end{array}$ & $2 n=4 x$ & [82] \\
\hline Salix viminalis $\mathrm{L}$. & $\begin{array}{l}\text { Larger leaves and stem diameter; enlarged bark and wood layers; } \\
\text { better developed root system }\end{array}$ & $2 n=4 x$ & [75] \\
\hline Taraxacum kok-saghyz Rodin. & $\begin{array}{l}\text { Larger stomata cells; decrease in stomata cells density; fewer leaves; } \\
\text { larger, thicker and dark green leaves; larger seeds }\end{array}$ & $2 \mathrm{n}=4 \mathrm{x}$ & [69] \\
\hline
\end{tabular}

${ }^{1} 2 x$ - diploid, ${ }^{2} 3 x$ - triploid, $^{3} 4 x$ - tetraploid, $^{4} 6 x$-heksaploid, ${ }^{5} 8 x$-oktoploid.

Lower density is usually the result of an increase in the size of the stomata and epidermal cells and the result of less differentiation of the stomata [103]. An example may be $C$. sativa, where tetraploid plants had half as many stomata on the underside of their leaves compared to diploids. Additionally, their stomata were about 30\% larger [74]. In contrast, Cannabis triploids had intermediate-sized stomata compared to diploids and tetraploids, while the stomata density decreased with increasing ploidy [49]. In the case of tetraploid Ocimum basilicum L., the length of the stomata was about $89 \%$ greater than in diploids; the diameter was also greater, while the density was about $63 \%$ less. Also, the mean length of the stomata was $77 \%$ greater than in diploids [89]. Tetraploids 
of E. purpurea also had larger stomata than diploid forms. In contrast, the density of stomata in this species decreased by almost one-third [104]. Comparable results and relationships have been reported for tetraploid plants with medicinal properties, e.g., in Trachyspermum ammi L. [105], Aloe vera L. [106], Catharanthus roseus (L.) G Don [107], as well as energy plants, such as S. viminalis [75], P. tomentosa [82], M. sacchariflorus and M. sinensis [52] or hybrids $84 \mathrm{~K}$ Populus alba $\times$ Populus glandulosa [77].

Polyploids tend to have fewer leaves, flowers, spikelets, fruits etc., than diploids. The examples are tetraploids of J. curcas, in which the number of flowers per inflorescence, fruits per infructescence and seeds per fruit decreased significantly. This condition is explained by the lower pollen fertility of tetraploids and/or a slower rate of photosynthesis [5]. In contrast, tetraploids of $N$. alata develop more leaves at the flower-forming stage, more flowers and internodes than in diploids [66]. Similarly, more shoots and leaves are produced by tetraploids of C. roseus [107], while more pods by tetraploids of Trigonella foenum-graecum L. [108].

The shape and size of individual organs also change. The leaves of polyploids tend to be broader, thicker, often intensely green, and covered with more hairs than in diploids. Thicker and dark green leaves are found in tetraploids of O. basilicum [89], T. vulgaris [79], N. alata [66]. Different leaf shapes and margins can be observed in polyploid Tetradenia riparia (Hochst) Codd, used in the pharmaceutical and perfume industry [95]. Thicker, greener and much larger leaves are found in tetraploids of $A$. vera [109], Eucalyptus globulus Labill. [110], T. foenum-graecum [108], Lavandula angustifolia subsp. angustifolia Mill. [4], E. purpurea [104], Zingiber officinale Roscoe [111], T. kok-saghyz [69] or Allium sativum L. [112] than in isogenic diploids. On the other hand, shorter and narrower leaves, especially in the central part of the main and lateral shoots, were obtained in hop tetraploids [73] (Figure 1). Contrasting results were obtained by Švécarová et al., where the leaves of tetraploids of H. lupulus were larger than in diploids, and their shape changed [78]. For example, in certain species, C. roseus, polyploidisation did not significantly change the leaf size, thickness or colour, but increased the total number of leaves, resulting in increased biomass [107].
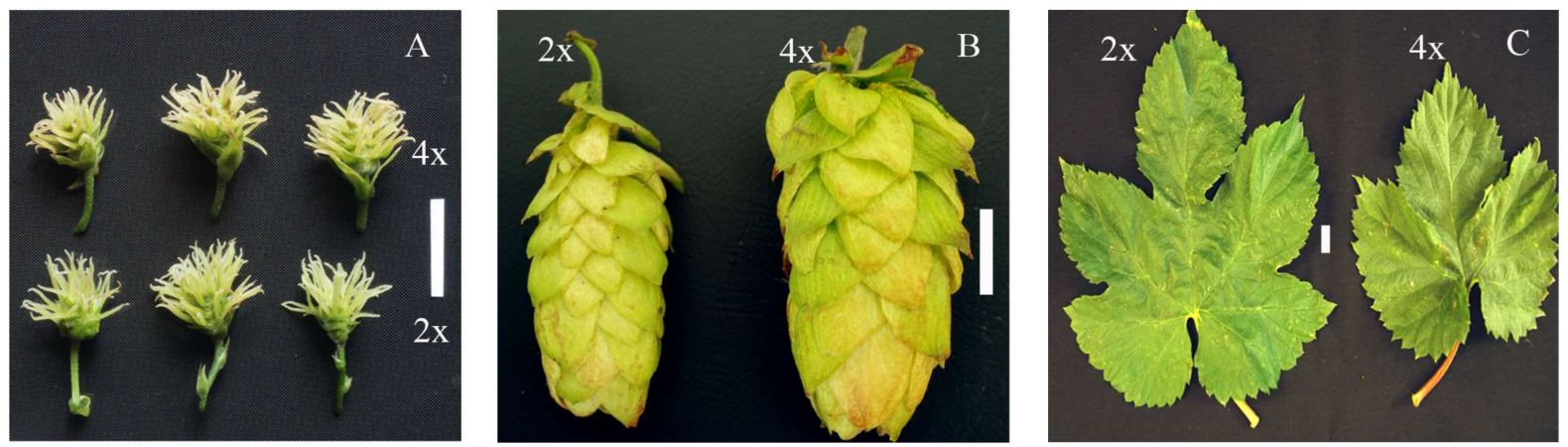

Figure 1. Flowers, hop cones and leaves of diploid and tetraploid H. lupulus "Sybilla": (A) female flowers of diploid (down) and tetraploid (up) plants (bar = $10 \mathrm{~mm}),(\mathbf{B})$ hop cones of diploid (left) and tetraploid (right) plants (bar = $20 \mathrm{~mm})$ and (C) fully expanded leaves of diploid (left) and tetraploid (right) plants (bar = $10 \mathrm{~mm}$ ) [55].

The effect of polyploidisation may also result in changes in stem and shoot shape, internode length, flower, seed, pollen grain and root size, and seed setting ability. Stems with a larger diameter were found in tetraploids of M. sinensis [52], T. ammi [105] and hexaploids of $M . \times$ giganteus [13] compared to diploid and triploid forms, respectively. Larger flowers and seeds were recorded in tetraploids of E. purpurea [104], J. curcas [5] or Matricaria chamomilla L. [3] as compared to diploids. Fewer seeds were produced by tetraploids of Cichorium intybus L. [90] or E. purpurea [104], whereas in the former species, the seeds in terms of size were the same as in diploids, while in coneflower, they were larger. Significantly larger pollen grains were in tetraploids than in diploids of O. basilicum [89] or C. intybus [90]. 
According to Dabholkar [113], triploids of Beta vulgaris L. produced larger roots than diploids. Increased biomass contributed to increased sugar yield in this species. Polyploids of Panax ginseng Mayer formed thicker roots with more abundant and shorter lateral roots than the control plants' roots. The root biomass obtained after six weeks of culture in the bioreactor was about 1.5 times higher for mutant roots than for the control roots [114]. Tetraploids of E. purpurea also produced fewer, thicker roots with more lateral roots compared to diploids [76,115].

It has also been shown that a change in the surface to volume ratio of a cell leads to a slowing down of vital processes, e.g., a decrease in transpiration [116]. Despite the increase in the size of the stomata, the intercellular gas exchange in tissue with large-cell (polyploid) structures is weaker than the small-cell structure because the intercellular spaces are reduced. Lower stomatal conductance by 24.19 and $67.74 \%$, respectively, was found in tetraploids and octoploids of J. curcas compared to diploids. In contrast, the leaves of tetraploids of $S$. viminalis showed elevated stomatal conductance values and increased water demand. In addition, they displayed increased $\mathrm{CO}_{2}$ assimilation and a rapid increase in biomass production [75]. Slower growth rates, especially in the early stages, may be due to slower rates of cell division, reduced metabolic rate or lower amounts of growth hormones, among other things [106]. Tetraploids with initial slow growth may include, for example, A. vera [106], A. sativum [112], S. viminalis [75] or E. purpurea [117].

As reported by Trojak-Goluch and Skomra [73] as well as Švécarová et al. [78], hop tetraploids showed poorer acclimatisation to field conditions and poorer rooting. Similar traits were displayed by tetraploids of T. vulgaris [79] and C. sativa [74]. Contrasting results were obtained by Tang et al. for tetraploids of $P$. tomentos $a$, whose seedlings were characterised by a strong root system and high acclimatisation ability (90\%) [82].

Many literature reports indicate that the size of polyploid plants is different from that recorded in diploids. In some species, polyploid forms are larger and stronger compared to diploid forms, e.g., in T. vulgaris [79], T. ammi [105], M. chamomilla [3], A. vera [106,109], Z. officinale [111]. In many other species, such as C. sativa [74,101], C. intybus [90], E. purpurea [104,115], polyploid plants are lower, or changes are hardly noticeable. The optimum degree of ploidy of a particular species, beyond which there are disturbances in tissue structure, development, a decrease in viability and productivity, is determined experimentally. Yue et al. showed that in Panicum virgatum L., used for biofuel production, tetraploids were significantly taller, had more shoots and had higher fresh weight than octoploids [118]. In turn, in S. officinarum, the optimum degree of ploidy is reached at the octoploid level [15]. Comparison of J. curcas plants differing in their degree of ploidy proved that tetraploids showed the best functional traits. These forms produced significantly larger leaves, flowers, fruits, seeds and pollen grains than diploids and octoploids [5]. For many industrial plants, including hops, the most favourable form of ploidy is three sets of chromosomes in the genome. Hop triploids are characterised by greater vigour and higher yields compared to diploids [88,119]. In addition, they exhibit a higher shoot twist index, which allows them to climb up on wires and fix on them better. An important feature of hop triploids is also the inability to set seeds. Sterile individuals are extremely useful in cultivation because they make it possible to produce seedless material, eliminating the need to clean the cones before using them in the fermentation process [85]. In turn, C. sativa, triploid sterility and lack of seeds promotes increased cannabinoid production and removes the need to remove male plants from the field [49]. Triploid cultivars from genus Salix obtained from controlled $2 \mathrm{x} \times 4 \mathrm{x}$ pollination are characterised by better vigour and yield than diploid and tetraploid species [44]. Another species in which the presence of three sets of chromosomes in the genome positively affects selected functional traits is $M . \times$ giganteus. It is characterised by high biomass productivity and low-temperature tolerance compared to the parental forms, diploid M. sinensis and tetraploid M. sacchariflorus [52]. Also, in the case of cultivars of the genus Populus, which are an important part of the world's timber industry, triploids are the most advantageous form of ploidy. 
They produce larger leaves with better quality and resistance to many diseases, give higher yields, are characterised by greater heterozygosity than the parental forms [36].

Delayed development and flowering are traits of, among others, tetraploids H. lupulus [73], C. intybus [90] or hexaploids of M. $\times$ giganteus. In Miscanthus $\times$ giganteus, the delay in the flowering of hexaploids compared to control triploids ranged from 2 to 17 weeks, which resulted in some plants not flowering before the onset of colder days [52]. Sometimes, however, the flowering of polyploids follows the same pattern as diploids. For example, tetraploids of $P$. tomentosa, whose flowering takes place similarly to diploids in the second year after planting, have the same course [82]. In contrast, tetraploids of $C$. sativa reach the flowering stage two weeks earlier than the control diploids [101].

Polyploidisation generally results in better plant adaptation to changing environmental conditions and increased resistance to biotic and abiotic factors. Tetraploids of Z. officinale had significantly more soluble proteins, sugars, and proline (PRO), substances associated with plant stress resistance [111]. Increased plant stress resistance is also associated with higher antioxidant enzyme activity as well as elevated levels of stress hormones $[75,120]$. Selected tetraploids of $S$. viminalis produced nearly twice the amount of salicylic acid and jasmonic acid compared to diploids. These hormones belong to a complex hormonal network that regulates, among other things, the growth of the root system. Tetraploids of Salix have a well-developed root system to better absorb nutrients and water even with limited availability and better adapt to adverse conditions [75]. Diploids of C. roseus can only grow in subtropical and tropical regions, while their tetraploid counterparts can colonise colder regions and thus, the range of cultivation and thus the yield of biomass obtained can be significantly increased [107]. It is similar in the case of T. foenumgraecum which is very rarely cultivated outside its natural habitat, and polyploidy gives the possibility to grow this plant in areas atypical of the usual range of this species [108]. In terms of the resistance of polyploids to fungal diseases, the response can vary between species and even cultivars. Hop triploids are characterised by rapid closure of cones after their formation, which significantly reduces the penetration of the pathogenic fungi Pseudoperonospora humuli and Podosphaera macularis. In addition, they produced more robust and less brittle cones when harvested [121].

Genome duplication is often accompanied by changes in secretory structures such as trichomes (glandular hairs), cells and secretory glands. Typically, there is an increase in the size of the cells that secrete and accumulate secondary metabolites while their number decreases [122]. Larger trichomes were observed on leaves, flowers and flower sepals of the tetraploids L. angustifolia subsp. angustifolia, whereas their density was similar to that in diploid lavender. As a result, the yield of lavender oil obtained in tetraploids was higher [4]. Mansouri and Bagheri [101] noted a significant decrease in trichome density in tetraploids of $C$. sativa. Parsons et al. obtained different results showing an increase in trichome density on leaves of tetraploid C. sativa by about $40.4 \%$ compared to diploids [74]. In the case of tetraploids of H. lupulus, lupulin glands were almost twice as large, while there were significantly fewer of them than in diploids. However, this had no significant effect on cone quality [73].

Literature reports also indicate that duplication of genetic material affects the structure of plant vascular bundles. In Linum usitatissimum L., fibrous cells decrease while cell walls become thicker with increasing genome dosage [123]. Similarly, as in tetraploids of C. sativa, less developed primary and secondary fibres were observed than in diploids, while xylem tissue was thicker [101]. Thicker wood layers in shoots were found in tetraploids of S. viminalis [75]. Corneillie et al., studying the effect of polyploidisation on plant growth and changes in cell wall composition, were investigated, and it was shown that polyploids develop more slowly than diploid counterparts, which was explained by changes in the composition of cell wall sugars [124]. In this study, ploidy growth correlated negatively with the lignin and cellulose content while positively with the polysaccharide matrix (hemicellulose and pectin) content in stem tissue. 


\section{Effects of Polyploidisation on the Amount and Composition of Secondary Plant Metabolites}

Increased ploidy is associated with an increase in the copy number of individual genes, which affects the content and activity of enzymes and metabolic pathways. This, in turn, determines the amount, composition, and proportions of secondary metabolites used commercially in various industries and the knowledge of mechanisms regulating the production of bioactive compounds [94]. According to Lavania [125], genome duplication causes a decrease in the ratio of the nuclear membrane to chromatin so that more chromatins comes in contact with the nuclear membrane, which enhances the genetic activity of the cell and the production of secondary metabolites.

Triploids of $H$. lupulus produced better quality raw material with higher content of soft resins, including $\alpha$-acids, than diploid plants [102]. An increase in $\alpha$-acids and some essential oil components such as humulene and caryophyllene in cones of triploid cultivars compared to diploid mother forms was reported by Probasco et al. [119]. On the other hand, in hop tetraploids, the composition of the major chemical compounds used in beer production changed little with genome doubling compared to diploids. The total essential oil content was lower, while the proportion of selected beneficial oils such as humulene, limonene, caryophyllene and farnesene was higher [73]. The species of interest to the pharmaceutical industry is $C$. roseus. It contains more than 130 terpenoid indole alkaloids (TIAs), among which vinblastine and vincristine show the strongest anticancer activity. Polyploidisation of $C$. roseus caused an increase in the expression of genes encoding enzymes involved in alkaloid biosynthesis and thus increased the content of vindoline, catharanthine and vinblastine in leaves by $130.9 \%, 188.6 \%$, and $122.6 \%$, respectively, above the content of these compounds in diploids. Therefore, the polyploidisation procedure can be used to produce plants with higher contents of desirable alkaloids for commercial use [107]. Another species, important for the medical use of its secondary metabolites such as tetrahydrocannabinol (THC), cannabidiol (CBD) and terpenes is C. sativa. Compounds extracted from Cannabis have been used to treat epilepsy, chronic pain or eliminate nausea associated with anticancer treatments [74]. Induced polyploidisation of $C$. sativa offers the potential for increased plant biomass and thus increased production of desirable compounds. To date, there has been only one report of the natural tetraploid C. sativa, which was identified in India [49]. Thus, in vitro works on the polyploidisation of Cannabis are being carried out to increase the production of desired secondary metabolites and obtain new cultivars with specific chemical profiles. Parsons et al. [74] obtained in vitro tetraploids of Cannabis with a $71.5 \%$ increase in total leaf terpene content and an altered profile of these compounds relative to diploids. The amount of CBD increased by $8.9 \%$, especially in female flower buds, while the THC content did not change. In contrast, Mansouri and Bagheri [101] obtained Cannabis tetraploids with lower THC content than control diploids. This is an example of how polyploidisation does not always result in an increase in the amount of desired secondary metabolites but sometimes in a decrease, most likely due to suppression of certain genes. The aforementioned authors also obtained mixoploids of $C$. sativa, which contained more total proteins, soluble sugars, and cannabinoids compared to diploids and tetraploids. The increased amount of total proteins in mixoploids was likely due to the enhanced expression of protein-coding genes resulting from the neighbouring diploid and polyploid cells. In addition, the higher amount of cannabinoids in Cannabis mixoploids was influenced by the higher number of trichomes producing these compounds [101]. In the case of $M . \times$ giganteus, hexaploid forms produced fewer phenolic compounds than their triploid counterparts. This was due to modification of gene expression involving repression and/or derepression of genes of the phenolic compound biosynthesis pathway [126]. Studies on the relationship between ploidy level and cichoric acid content in E. purpurea were conducted by Li et al. [117]. The obtained results indicated that the content of cichoric acid in the aboveground and underground parts of octoploids of E. purpurea was higher than in tetraploid and diploid seedlings. Changes in the proportions of individual compounds were also studied in other species. A 
significant increase in morphine production and a decrease in thebaine and codeine were found in polyploid Papaver somniferum L. [127], and the change in the ratio of oxygenated to non-oxygenated monoterpenes in Lippia integrifolia (Griseb.) Hieron [80]. Not only can the proportions of metabolites change, but also the overall composition of the metabolites. In the case of tetraploids of T. ammi obtained by polyploidisation of germinated seeds showed an increase in thymol content as a component of essential oil up to $69.2 \%$ compared to diploid plants in which its content was $49.67 \%$. In addition, the essential oil composition of tetraploids changed, lacking $\alpha$-terpineol, a component that was present in diploids [105]. The same was true for T. riparia tetraploids, in which as many as three additional essential oil components appeared $\alpha$-humulene, $\alpha$-terpineol, and viridiflorol [95]. Changes in the chemical profiles of metabolites in tetraploids result from disruptions in the metabolic mechanisms that regulate the biosynthesis of particular compounds. The absence of a given compound is explained by inhibition of expression of the structural gene encodes it, whereas the appearance of new compounds is explained by a lack of inhibition of expression of previously silenced genes [128].

An industrial plant that produces the natural rubber cis 1,4-polyisoprene is T. kok-saghyz. It may be an alternative source of this important compound produced mainly by $\mathrm{H}$. brasiliensi. The advantage of T. kok-saghyz is the ability to colonise areas with colder climates, high rubber production potential, high population diversity, and the disadvantage of poor plant vigour. Genome polyploidisation has emerged as a method to improve certain morphological traits while increasing rubber concentration. Luo et al. obtained tetraploids of T. kok-saghyz, producing 47.7\% more rubber than diploid plants [69]. Unfortunately, due to the shortening of the roots in tetraploids of the null generation (G0), probably caused by colchicine treatment, the amount of rubber obtained per root mass was not significantly different from that in diploids. The actual effect of polyploidisation on root growth and rubber concentration can be estimated in future generations. Another species producing an important metabolite, trans-1,4-polyisoprene (TPI), used as an industrial raw material, is E. ulmoides. Studies of the effect of polyploidisation on TPI content in this species showed no significant differences between tetraploids and diploids [67].

To date, many studies have been conducted on the effects of polyploidisation on the production by plants of desirable compounds used in the pharmaceutical industry $[3,90,105,110-112,115,127,129]$ and/or the cosmetic industry $[3,109,114,130]$ or as natural insecticides [79].

\section{The Use of Polyploids in the Breeding of Industrial Plants}

\subsection{Improvement of Agronomic Performance of Industrial Plants}

The induction of polyploids used in the breeding of industrial plants has been applied since the 1950s [131]. It was intended to use the advantageous traits of polyploids and introduce them to cultivated varieties. The breeding work began with the production of autotetraploids. Already in the 1950s, tetraploids of L. usitatissimum, C. sativa and various species of herbal plants were produced. Mutant plants were obtained by the use of colchicine or high temperatures. Autotetraploids have generally failed to meet the expectations of direct use. In the case of flax, the fibre and fat contents were lower compared to the diploid forms. Likewise, in hemp, the fibre content of tetraploid forms was lower than that of diploids. The fibre quality was also worse [132]. However, this does not mean that the indirect use of tetraploids is not currently used in other species of industrial plants. On the other hand, it is limited to species whose significant functional trait is a high yield of biomass, increased size of vegetative parts and the content of biochemical substances. For example, in herbal plants, polyploidisation is especially intensified in Chamomilla recutita (L.) Rausch. Because of the increased number of gene copies present in polyploids, artificially induced polyploidy led to increases in enzymatic content and activity and several other effects that contribute to enhanced production and qualitative changes in secondary metabolites. Colchicine application in chamomile started in Europe around the 1950s. In 1962, the first tetraploid $(4 x=36)$ variety, named "Bodegol", was developed and released as a cultivar in Germany. In the following decades, tetraploid 
varieties were released by other countries, such as Slovakia ("Goral" and "Lutea" in 1995), Poland ("Zloty Lan" in 1972 and "Dukat" in 2006), Romania ("Flora" and "Margaritar") and Bulgaria ("Lazur" in 1980). The tetraploid forms of chamomile outperform their diploid relatives in biochemical and morphological traits, such as in the quantity of essential oils, bisaboloids, chamazulene, apigenin and flavonoids, as well as in the higher height, capitulum size and weight and dry seed weight. The cultivated tetraploid chamomile varieties "Lutea" and "Goral", for instance, have been shown to produce higher levels (above 20\%) of chamazulene, one of the valuable medicinal components of chamomile essential oil, than diploid cultivars [133]. In addition to increasing the content of active substances, tetraploid varieties of chamomile are also characterised by a higher yield of raw material than diploids. For example, polish chamomile varieties "Dukat" and "Zloty Lan" show a high yield of dried flowers and larger flowers than their diploid counterparts. They are also better suitable for mechanical harvest [134]. Today, almost one-quarter of the chamomile varieties cultivated worldwide are tetraploids induced by colchicine, highlighting the success of polyploidy breeding establishment in this medicinal crop [3].

Autotetraploids are also used in the breeding of high-yielding varieties of energy plants. For example, some tetraploid lines of miscanthus are characterised by a significantly higher yield of biomass than diploid and triploid forms. However, for the most part, the cultivation of triploid forms is the most profitable. Tetraploid plants were also studied in Jatropha curcas, one of the greatest potential biofuel plants. It is a promising goal of breeding work; thus, high-yielding varieties are considered the highest priority for study [135].

For different purposes, tetraploids in Cnidium officinale Makino and C. sativa are produced. C. officinale is an important medicinal crop grown for its pharmacological properties. Tetraploid breeding was conducted to increase the content of medicinal compounds and tolerance to environmental conditions [136]. As mentioned, the induction of tetraploids in hemp was abandoned due to the lower quality and lower yield of fibre compared to diploids. However, today, the hemp breeding goals are fundamentally different. The medical use of these plants arouses the greatest interest. The varieties obtained today belong mainly to the cannabinoid-seed type. They have a compact habit and more abundant inflorescences than fibre-type varieties (Figure 2). The direction of seed production for the food industry is also developing dynamically. Mansouri and Bagheri reported the production of putative tetraploid plants of $C$. sativa, with the ultimate aim of improving this plant's medicinal and physiological traits [101].

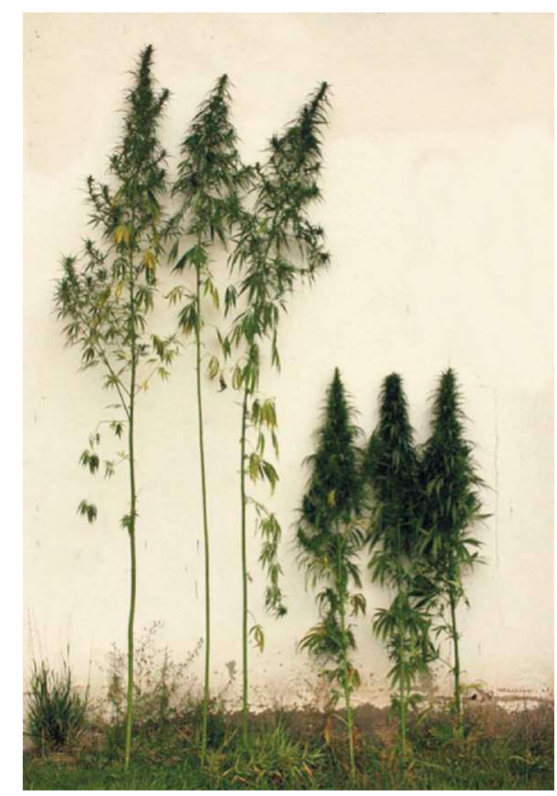

Figure 2. Plant habit of Cannabis sativa. The fibrous type variety (left) and the cannabinoid-seed type variety (right). 
Cotton remains the most important fibre-bearing crop worldwide. The Gossypium genus is represented by species, divided into two levels of ploidy: diploid $(2 n=26)$ and tetraploid $(2 n=52)$ [137]. Cotton tetraploids are alloploids resulting from the crossing of diploid species.

Research on the tetraploid genome of cotton is carried out frequently and focuses on the location of genes determining the quality of the fibre based on determining the elongation mechanisms of cells and cell walls [12,138]. According to Jiang et al., none of the diploid cotton species provides fibres with the same high-quality yield as the two AADD allotetraploid species [12]. Renny-Byfield and Wendel [139] concluded that a combination of A to D genomes resulted in the polyploid hybrid, producing better quality fibre for both diploid parents.

\subsection{Triploid Breeding Strategy}

In the breeding of industrial plants, polyploids are also often used indirectly as a tool to generate the desired genotypes or overcome genetic barriers. Chromosome mutations provide new sources of variation. Tetraploids are commonly used in industrial plant breeding as parental forms to produce triploid varieties. Due to their sterility, triploids are used in species where it is not desired for plants to produce seeds. A typical example of the use of triploid varieties in cultivation is hop. Triploid varieties of hop are characterised by a reduced number of seeds in cones, which eliminates the need for additional cleaning before the grinding process. Moreover, triploid forms increase the taste of beer, resulting from the raw materials better quality [121]. The triploid varieties are obtained in the traditional method by crossing the tetraploid and diploid forms. There are many other examples of the practical use of triploids in industrial plants breeding. Triploid hybrid aspen was produced by crossing highly selected diploid female Populus tremuloides Michx. clones with a single male tetraploid P. tremula. The trees were characterised by a faster growth rate, greater wood density, and better pulp properties [140]. Crossing a tetraploid P. tremula with pollen of a diploid Canadian P. tremuloides, the fast-growing triploid hybrid aspen clone "Astria" was produced too [141]. The most common method of breeding triploid plants is the application of spontaneous or induced diploid pollen. In many breeding studies [142,143], enriched diploid pollen was applied for in vitro pollinations and crossbreeding to produce high-performance triploid hybrids. Enriched diploid pollen was obtained by size fractionation of naturally unreduced pollen and heat treatment of microspore mother cells. In addition to crossings within the section Populus, intersectional crossbreeding was performed combining the benefits of intersectional hybridisation with those derived from triploidisation [144]. 2n pollen induction in $P$. x popularis made it possible to obtain polyploids in two sections other than Populus [145]. Obtaining poplar triploids by induction of $2 \mathrm{n}$ eggs is also reported, although much less frequent $[146,147]$. Triploids of poplar have also been bred using diploid $P . \times$ tomentosa pollen in crosses with P. alba $\times$ P. glandulosa $\mathrm{F}_{1}$ hybrid females [147].

\subsection{Advantages of Polyploidy for Interspecific Hybridisation}

Another important function of polyploids is the possibility of their use in interspecific crossing. In the case of industrial plants, the interspecific crossing is used to obtain hybrids with the desired valuable properties of the raw material, as well as translates into higher resistance to biotic and abiotic stress factors. For example, the interspecific crossing of Nicotiana tabacum may transfer the resistance to Potato virus Y (PVY) from wild species to cultivated forms. The donor of genetic resistance to PVY is the species N. africana Merxm. [148]. Crossbreeding $N$. tabacum $\times N$. africana allowed obtaining amphihaploids containing a single set of chromosomes of each parental species, then doubling the number of chromosomes has produced fertile amphidiploid forms. Cytological analysis of successive hybrid generations and biological resistance tests allowed obtaining BPA breeding lines tolerant to this virus. In turn, obtaining tobacco lines resistant to Thielaviopsis basi- 
cola Berk. and Broome was achieved by interspecific pollination between tetraploids of N. tabacum with Nicotiana glauca Grah. species [149].

In interspecific crossing, polyploids also have a key role in breaking barriers to infertility in the produced hybrids. The success of crossing two different species depends on the fertility of the hybrids. In turn, fertility depends on how were closely related the parental forms. If the parental forms are closely related, the hybrid is usually fertile; however, the hybrid is usually infertile if they are genetically distant. Doubling the number of chromosomes in polyploids such a hybrid leads to fertility. The chromosomes are then homologous, meiosis is normal, and the plant can produce the seeds. This method was used for breeding high fescue grass (F. arundinacea Schreb.) from Italian ryegrass $(2 n=2 x=14)$ and tall fescue $(2 \mathrm{n}=6 \mathrm{x}=42)$ by using meadow grass (F. pratensis) as a bridge species [22,150]. An example of the use of allopolyploids among industrial plants is poplar. Allopolyploids are very common in poplar production. Due to interspecific crossbreeding in individual sections, plants with faster weight gain are obtained.

\section{Perspectives of Using Polyploids in Plant Breeding}

There are very broad prospects for the use of polyploids in the breeding of industrial species. This applies both to maintaining the current directions of work that are difficult to replace in any other way, as well as new, innovative scientific research. The production of sterile fruits and the use of polyploids in bridge crossing between different species will certainly be maintained. Due to their higher mutation frequency, polyploids will also be used in the mutation breeding of industrial plants [151]. The effects of permanent changes in the genome are often unpredictable, and this direction of breeding work will undoubtedly be continued.

Innovative research on the resistance of polyploids to different stress conditions and economically important diseases is currently conducted on a large scale [152]. High adaptive properties of polyploid plants can be used in the context of breeding new varieties of industrial plants well adapted to changing climatic conditions [153].

The newest research on the innovative application of hemp raw materials and herbal plants also relates to the use of tetraploids. The properties of tetraploids are currently being used to increase the yield of industrial hemp biomass as a raw material for the production of second-generation biofuels. In addition to a higher yield of biomass, the effect of polyploidisation on the content of components such as cellulose, hemicellulose and lignin, the proportions of which have a significant impact on the processing of hemp biomass into bioethanol or biohydrogen, is also studied.

Tetraploids are also tested and will certainly be tested in many species of herbal plants in the future. Studies planned to be carried out in Poland concerns, for example, an assessment of the Scutellaria baicalensis variability and the induction of polyploids of this species in in vitro cultures in order to improve the quality of the obtained herbal material in the form of increasing the root biomass and the content of flavonoids [154]. It is assumed that the natural variability of the Scutellaria baicalensis will be a good starting point for selecting perspective genotypes characterised by high yielding of herbal raw material and the content of major bioactive compounds and obtaining autotetraploids will additionally improve the quality of the plant material [155].

Author Contributions: Conceptualisation, A.T.-G. and M.K.-L.; writing-original draft, A.T.-G., M.K.-L., K.W. and M.P.; visualisation, A.T.-G. and M.K.-L.; supervision, A.T.-G.; funding acquisition, A.T.-G. All authors have read and agreed to the published version of the manuscript.

Funding: The study was financed from a targeted grant for the implementation of the task 5, entitled "Breeding and seeding of crop plants", funded by the Polish Ministry of Agriculture and Rural Development for the year 2021.

Institutional Review Board Statement: Not applicable.

Informed Consent Statement: Not applicable. 


\section{Data Availability Statement: Not applicable.}

Conflicts of Interest: The other authors declare no conflict of interest.

\section{References}

1. Wood, T.E.; Takebayashi, N.; Barker, M.S.; Mayrose, I.; Greenspoon, P.B.; Rieseberg, L.H. The frequency of polyploid speciation in vascular plants. Proc. Natl. Acad. Sci. USA 2009, 106, 13875-13879. [CrossRef]

2. Hegarty, M.J.; Coate, S.; Sherman-Broyles, R.; Abbott, R.J.; Hiscock, S.; Doyle, J. Lessons from natural and artificial polyploids in higher plants. Cytogenet. Genome Res. 2013, 140, 204-225. [CrossRef] [PubMed]

3. Das, M. Chamomile: Medicinal, Biochemical, and Agricultural Aspects; CRC Press: New York, NY, USA, 2015; ISBN 978-1-4665-7759-6.

4. Urwin, N.A.R.; Horsnell, J.; Moon, T. Generation and characterisation of colchicine-induced autotetraploid Lavandula angustifolia. Euphytica 2007, 156, 257-266. [CrossRef]

5. Niu, L.; Tao, Y.; Chen, M.; Fu, Q.; Dong, Y.; He, H.; Xu, Z. Identification and characterization of tetraploid and octoploid Jatropha curcas induced by colchicine. Caryologia 2016, 69, 58-66. [CrossRef]

6. Grant, V. Plant Speciation; Columbia University Press: New York, NY, USA, 1981.

7. Wendel, J.F. Genome evolution in polyploids. Plant Mol. Biol. 2000, 42, 225-249. [CrossRef] [PubMed]

8. Adams, K.L.; Wendel, J.F. Polyploidy and genome evolution in plants. Curr. Opin. Plant Biol. 2005, 8, 135-141. [CrossRef] [PubMed]

9. Stebbins, G.L. Variation and Evolution in Plants; Oxford University Press: London, UK, 1950.

10. Ramsey, J.; Schemske, D.W. Neopolyploidy in flowering plants. Annu. Rev. Ecol. Syst. 2002, 33, 589-639. [CrossRef]

11. Tate, J.A.; Soltis, D.E.; Soltis, P.S. Polyploidy in Plants. In The Evolution of the Genome; Gregory, T.R., Ed.; Academic Press: Cambridge, MA, USA, 2005; pp. 371-426. [CrossRef]

12. Jiang, C.-X.; Wright, R.J.; El-Zik, K.M.; Paterson, A.H. Polyploid formation created unique avenues for response to selection in Gossypium (cotton). Proc. Natl. Acad. Sci. USA 1998, 95, 4419-4424. [CrossRef]

13. Głowacka, K.; Jeżowski, S.; Kaczmarek, Z. The effects of genotype, inflorescence developmental stage and induction medium on callus induction and plant regeneration in two Miscanthus species. Plant Cell Tissue Organ Cult. 2010, 102, 79-86. [CrossRef]

14. Berbeć, A.; Doroszewska, T. The Use of Nicotiana Species in Tobacco Improvement. In The Tobacco Plant Genome. Compendium of Plant Genomes; Ivanov, N., Sierro, N., Peitsch, M., Eds.; Springer: Cham, Switzerland, 2020.

15. Premachandran, M.N.; Prathima, P.T.; Lekshmi, M. Sugarcane and polyploidy-A review. J. Sugarcane Res. 2011, 1, 1-15.

16. Bertioli, D.J.; Jenkins, J.; Clevenger, J.; Dudchenko, O.; Gao, D.; Seijo, G.; Leal-Bertioli, S.C.M.; Ren, L.; Farmer, A.D.; Pandey, M.K.; et al. The genome sequence of segmental allotetraploid peanut Arachis hypogaea. Nat. Genet. 2019, 51, 877-884. [CrossRef] [PubMed]

17. Sattler, M.C.; Carvalho, C.R.; Clarindo, W.R. The polyploidy and its key role in plant breeding. Planta 2016, 243, 281-296. [CrossRef] [PubMed]

18. Ramsey, J.; Schemske, D.W. Pathways, Mechanisms, and Rates of Polyploid Formation in Flowering Plants. Annu. Rev. Ecol. Syst. 1998, 29, 467-501. [CrossRef]

19. Zhang, Z.; Fu, T.; Liu, Z.; Wang, X.; Xun, H.; Li, G.; Ding, B.; Dong, Y.; Lin, X.; Sanguinet, K.A.; et al. Extensive changes in gene expression and alternative splicing due to homoeologous exchange in rice segmental allopolyploids. Theor. Appl. Genet. 2019, 132, 2295-2308. [CrossRef]

20. Sybenga, J. Chromosome pairing affinity and quadrivalent formation in polyploids: Do segmental allopolyploids exist? Genome 1996, 39, 1176-1184. [CrossRef]

21. Doyle, J.; Coate, J. Polyploidy, the nucleotype, and novelty: The impact of genome doubling on the biology of the cell. Int. J. Plant Sci. 2019, 180, 1-52. [CrossRef]

22. Comai, L. The advantages and disadvantages of being polyploid. Nat. Rev. Genet. 2005, 6, 836. [CrossRef]

23. Kopecký, D.; Felder, T.; Schubiger, F.X.; Václav Mahelka, V.; Bartoš, J.; Doležel, J.; Boller, B. Frequent occurrence of triploid hybrids Festuca pratensis $\times$ F. apennina in the Swiss Alps. Alp. Bot. 2018, 128, 121-132. [CrossRef]

24. Heaton, E.A.; Dohleman, F.G.; Miguez, A.F.; Juvik, J.A.; Lozovaya, V.; Widholm, J.; Zabotina, O.A.; Mcisaac, G.F.; David, M.B.; Voigt, T.B.; et al. Miscanthus: A promising biomass crop. Adv. Bot. Res. 2010, 56, 75-137. [CrossRef]

25. Stebbins, G.L. Chromosomal Evolution in Higher Plants; Edward Arnolds Publ.: London, UK, 1971; pp. 43-46.

26. Ehrendorfer, F. Polyploidy and Distribution. In Polyploidy, Biological Relevance; Lewis, W.H., Ed.; Plenum Press: New York, NY, USA; London, UK, 1980; pp. 45-60.

27. Jackson, S.; Chen, Z.J. Genomic and expression plasticity of polyploidy. Curr. Opin. Plant Biol. 2010, 13, 153-159. [CrossRef]

28. Blakesley, D.; Allen, A.; Pellny, T.K.; Roberts, A.V. Natural and induced polyploidy in Acacia dealbata Link and Acacia mangium Willd. Ann. Bot. 2002, 90, 391-398. [CrossRef] [PubMed]

29. Dzialuk, A.; Chybicki, I.; Welc, M.; Śliwińska, E.; Burczyk, J. Presence of Triploids among Oak Species. Ann. Bot. 2007, 99, 959-964. [CrossRef] [PubMed]

30. Bretagnolle, F.; Thompson, J.D. Gametes with the somatic chromosome number: Mechanisms of their formation and role in the evolution of autopolyploid plants. New Phytol. 1995, 129, 1-22. [CrossRef] [PubMed]

31. van Dijk, P.J.; Bakx-Schotman, J.M. Formation of unreduced megaspores (diplospory) in apomictic dandelions (Taraxacum officinale, s.1.) is controlled by a sex-specific dominant locus. Genetics 2004, 166, 483-492. [CrossRef] [PubMed] 
32. Trojak-Goluch, A.; Berbeć, A. Cytological investigations of the interspecific hybrids of Nicotiana tabacum L. $\times$ N. glauca Grah. J. Appl. Genet. 2003, 44, 45-54.

33. Montes, E.; Coriton, O.; Eber, F.; Huteau, V.; Lacape, J.M.; Reinhardt, C.; Marais, D.; Hofs, J.L.; Chèvre, A.M.; Pannetier, C. Assessment of Gene Flow Between Gossypium hirsutum and G. herbaceum: Evidence of Unreduced Gametes in the Diploid Progenitor. G3-Genes Genom. Genet. 2017, 7, 2185-2193. [CrossRef]

34. van Laere, K.; Dewitte, A.; van Huylenbroeck, J.; van Bockstaele, E. Evidence for the occurrence of unreduced gametes in interspecific hybrids of Hibiscus. J. Hortic. Sci. Biotechnol. 2009, 84, 240-247. [CrossRef]

35. Sora, D.; Kron, P.; Husband, B. Genetic and environmental determinants of unreduced gamete production in Brassica napus, Sinapis arvensis and their hybrids. Heredity 2016, 117, 440-448. [CrossRef]

36. Lu, M.; Zhang, P.; Kang, X. Induction of $2 \mathrm{n}$ female gametes in Populus adenopoda Maxim by high temperature exposure during female gametophyte development. Breed. Sci. 2013, 63, 96-103. [CrossRef] [PubMed]

37. Wang, J.; Li, D.L.; Kang, X.Y. Induction of unreduced megaspores with high temperature during megasporogenesis in Populus. Ann. For. Sci. 2012, 69, 59-67. [CrossRef]

38. Amdahl, H.; Aamlid, T.S.; Ergon, Å.; Kovi, M.R.; Marum, P.; Alsheikh, M.; Rognli, O.A. Seed yield of Norwegian and Swedish tetraploid red clover (Trifolium pratense L.) populations. Crop Sci. 2016, 56, 603-612. [CrossRef]

39. Kostoff, D. Studies on polyploid plants. XVIII. Cytogenetic studies on Nicotiana sylvestris $\times$ N. tomentosiformis hybrids and amphidiploids and their bearings on the problem of the origin of N. tabacum. Crit. Rev. Acad. Sci. 1938, 18, 459-462.

40. Clausen, R.E.; Goodspeed, T.H. Interspecific hybridization in Nicotiana. II. A tetraploid glutinosa-tabacum hybrid, an experimental verification of Winge's hypothesis. Genetics 1925, 10, 278-284. [CrossRef]

41. Haunold, A. Cytology, sex expression and growth of a tetraploid $\times$ diploid cross in hop (Humulus lupulus L.). Crop Sci. 1971, 11, 868-871. [CrossRef]

42. Beatson, R.A.; Brewer, V.R. Regional trial evaluation and cultivar selection of triploid hop hybrids. N. Z. J. Crop Hortic. Sci. 1994, 22, 1-6. [CrossRef]

43. Beatson, R.; Ferguson, A.; Weir, I.; Graham, L.T.; Ansell, K.A.; Ding, H. Flow cytometric identification of sexually derived polyploids in hop (Humulus lupulus L.) and their use in hop breeding. Euphytica 2003, 134, 189-194. [CrossRef]

44. Serapiglia, M.J.; Gouker, F.E.; Smart, L.B. Early selection of novel triploid hybrids of shrub willow with improved biomass yield relative to diploids. BMC Plant Biol. 2014, 14, 74. [CrossRef] [PubMed]

45. Hirayoshi, I.; Nishikawa, K.; Hakura, A. Cyto-genetical studies on forage plants (VIII) $3 \times$ and $4 \times$ hybrid arisen from the cross Miscanthus sinensis var. condensatus $\times$ Miscanthus sacchariflorus. Res. Bull. Fac. Agric. 1960, 12, 82-88.

46. Barney, J.N.; Ditomaso, J.M. Nonnative species and bioenergy: Are we cultivating the next invader? BioScience 2008, 58, 64-70. [CrossRef]

47. Li, Q.; Jiang, W.; Ren, Y.; Chen, R.; Li, X.; Yang, Y.; Wu, H. In vitro cloning potential and phytochemical evaluations of aneuploid individuals produced from reciprocal crosses between diploid and triploid in Echinacea purpurea L. Acta Soc. Bot. Pol. 2017, 86, 3556. [CrossRef]

48. Guo, Y.; Zhao, Y.; Li, K.; Liu, Z.; Lin, H.; Guo, X.; Li, C. Embryo rescue of crosses between diploid and tetraploid grape cultivars and production of triploid plants. Afr. J. Biotechnol. 2011, 10, 19005-19010. [CrossRef]

49. Kurtz, L.E.; Brand, M.H.; Lubell-Brand, J.D. Production of Tetraploid and Triploid Hemp. HortScience 2020, 55, $1703-1707$. [CrossRef]

50. Touchell, D.H.; Ranney, T.G. Chromosome doubling and fertility restoration in Miscanthus $\times$ giganteus. HortScience 2012, 47,334 . [CrossRef]

51. Chen, Y.; Liu, G.; Ma, H.; Song, Z.; Zhang, C.; Zhang, J.; Zhang, J.; Wang, F.; Zhang, J. Identification of Introgressed Alleles Conferring High Fiber Quality Derived from Gossypium barbadense L. in Secondary Mapping Populations of G. hirsutum L. Front. Plant Sci. 2018, 9, 1023. [CrossRef] [PubMed]

52. Chae, W.B.; Hong, S.J.; Gifford, J.M.; Rayburn, A.L.; Widholm, J.M.; Juvik, J.A. Synthetic polyploid production of Miscanthus sacchariflorus, Miscanthus sinensis, and Miscanthus $\times$ giganteus. GCB Bioenergy 2013, 5, 338-350. [CrossRef]

53. Nishiwaki, A.; Mizuguti, A.; Kuwabara, S.; Toma, Y.; Ishigaki, G.; Miyashita, T.; Yamada, T.; Matuura, H.; Yamaguchi, S.; Rayburn, A.L.; et al. Discovery of natural Miscanthus (Poaceae) triploid plants in sympatric populations of Miscanthus sacchariflorus and Miscanthus sinensis in southern Japan. Am. J. Bot. 2011, 98, 154-159. [CrossRef]

54. Kinoshita, T.; Takahashi, M. Studies in polyploid varieties of sugar beets. XIV. Use of cytoplasmic male sterility in the production of triploid hybrids, and their performance in trials. J. Fac. Agric. Hokkaido Univ. 1969, 56, 171-186.

55. Finch, R.A.; Osborne, J.F. Chromosome numbers and DNA amount in Agave variants. East Afr. Agric. For. J. 1990, 55, 213-218. [CrossRef]

56. Kim, Y.M.; Kim, S.; Koo, N.; Shin, A.Y.; Yeom, S.-I.; Seo, E.; Park, S.J.; Kang, W.H.; Kim, M.-S.; Park, J.; et al. Genome analysis of Hibiscus syriacus insights of polyploidization and indeterminate flowering in woody plants. DNA Res. 2017, 24, 71-80.

57. Moutschen-Dahmen, J.; Moutschen-Dahmen, M. Radiation Induced Polyploidy in Nigella damascena. Caryologia 1970, $23,501-513$. [CrossRef]

58. Wang, J.; Shi, L.; Song, S.; Tian, J.; Kang, X. Tetraploid production through zygotic chromosome doubling in Populus. Silva Fenn. 2013, 47, 932. [CrossRef] 
59. Guo, L.; Xu, W.; Zhang, Y.; Zhang, J.; Wei, Z. Inducing triploids and tetraploids with high temperatures in Populus sect. Tacamahaca. Plant Cell Rep. 2017, 36, 313-326. [CrossRef] [PubMed]

60. Manzoor, A.; Ahmad, T.; Bashir, M.A.; Hafiz, I.A.; Silvestri, C. Studies on colchicine induced chromosome doubling for enhancement of quality traits in ornamental plants. Plants 2019, 8, 194. [CrossRef] [PubMed]

61. Morejohn, L.C.; Bureau, T.E.; Mole-Bajer, J.; Bajer, A.S.; Fosket, D.E. Oryzalin, a dinitroaniline herbicide, binds to plant tubulin and inhibits microtubule polymerization in vitro. Planta 1987, 172, 252-264. [CrossRef]

62. Petersen, K.K.; Hagberg, P.; Kristiansen, K. Colchicine and Oryzalin Mediated Chromosome Doubling in Different Genotypes of Miscanthus sinensis. Plant Cell Tissue Organ Cult. 2003, 73, 137-146. [CrossRef]

63. Talebi, S.F.; Saharkhiz, M.J.; Kermani, M.J.; Sharafi, Y.; Fard, F.R. Effect of different antimitotic agents on polyploidy induction of anise hyssop (Agastache foeniculum L.). Caryologia 2017, 70, 184-193. [CrossRef]

64. Cheng, Z.H.; Zhou, X.J.; Khan, M.A.; Su, L.; Meng, H.W. In vitro induction of tetraploid garlic with trifluralin. Genet. Mol. Res. 2012, 11, 2620-2628. [CrossRef] [PubMed]

65. Hansen, N.G.P.; Andersen, S.B. In vitro chromosome doubling with colchicine during microspore culture in wheat (Triticum aestivum L.). Euphytica 2000, 102, 101-108. [CrossRef]

66. El-Morsy, S.I.; Dorra, M.D.M.; Elham, A.A.A.E.-H.; Atef, A.A.H.; Ahmed, Y.M. Comparative studies on diploid and tetraploid levels of Nicotiana alata. Acad. J. Plant Sci. 2009, 2, 182-188.

67. Tokumoto, Y.; Kajiura, H.; Takeno, S.; Harada, Y.; Suzuki, N.; Hosaka, T.; Gyokusen, K.; Nakazawa, Y. Induction of tetraploid hardy rubber tree, Eucommia ulmoides, and phenotypic differences from diploid. Plant Biotechnol. 2016, 33, 51-57. [CrossRef]

68. Dhamayanthi, K.P.M.; Gotmare, V. Induction of polyploidy in two diploid wild cotton (G. armourianum and G. aridum) species by colchicine treatment. Electron. J. Plant Breed. 2010, 1, 966-972.

69. Luo, Z.; Iaffaldano, B.J.; Cornish, K. Colchicine-induced polyploidy has the potential to improve rubber yield in Taraxacum kok-saghyz. Ind. Crops Prod. 2018, 112, 75-81. [CrossRef]

70. Yang, N.; Rong, E.; Li, Q.; Dong, J.; Du, T.; Zhao, X.; Wu, Y. Tetraploid Induction and Identification of Gossypium arboreum. Agric. Sci. 2015, 6, 436-444. [CrossRef]

71. Głowacka, K.; Jeżowski, S.; Kaczmarek, Z. Polyploidization of Miscanthus sinensis and Miscanthus $\times$ giganteus by plant colchicine treatment. Ind. Crop. Prod. 2009, 30, 444-446. [CrossRef]

72. Maru, B.; Parihar, A.; Kulshrestha, K.; Vaja, M. Induction of polyploidy through colchicine in cotton (Gossypium herbaceum) and its conformity by cytology and flow cytometry analyses. J. Genet. 2021, 100, 52. [CrossRef]

73. Trojak-Goluch, A.; Skomra, U. Artificially induced polyploidization in Humulus lupulus L. and its effect on morphological and chemical traits. Breed. Sci. 2013, 63, 393-399. [CrossRef] [PubMed]

74. Parson, J.L.; Martin, S.L.; Golenia, G.; James, T. Polyploidization for the Genetic Improvement of Cannabis sativa. Front. Plant Sci. 2019, 10, 476. [CrossRef] [PubMed]

75. Dudits, D.; Török, K.; Cseri, A.; Paul, K.; Nagy, A.V.; Nagy, B.; Sass, L.; Ferenc, G.; Vankova, R.; Dobrev, P.; et al. Response of Organ Structure and Physiology to Autotetraploidization in Early Development of Energy Willow Salix viminalis. Plant Physiol. 2016, 170, 1504-1523. [CrossRef] [PubMed]

76. Nilanthi, D.; Chen, X.L.; Zhao, F.C.; Yang, Y.S.; Wu, H. Induction of tetraploids from petiole explants through colchicine treatments in Echinacea purpurea L. J. Biomed. Biotechnol. 2009, 2009, 343485. [CrossRef]

77. Ren, Y.; Jing, Y.; Kang, X. In vitro induction of tetraploid and resulting trait variation in Populus alba $\times$ Populus glandulosa clone 84 K. Plant Cell, Tissue Organ Cult. 2021, 146, 285-296. [CrossRef]

78. Švécarová, M.; Navrátilová, B.; Hašler, P.; Ondřej, V. Artificial induction of tetraploidy in Humulus lupulus L. using oryzalin. Acta Agrobot. 2019, 72, 1764. [CrossRef]

79. Navrátilová, B.; Švécarová, M.; Bednář, J.; Ondřej, V. In Vitro Polyploidization of Thymus vulgaris L. and Its Effect on Composition of Essential Oils. Agronomy 2021, 11, 596. [CrossRef]

80. Iannicelli, J.; Elechosa, M.A.; Juarez, M.A.; Martinez, A.; Bugallo, V.; Bandoni, A.L.; Escandon, A.S.; van Bare, C.M. Effect of polyploidization in the production of essential oils in Lippia integrifolia. Ind. Crop Prod. 2016, 81, 20-29. [CrossRef]

81. Le, K.C.; Lee, J.D.; Paek, K.Y.; Park, S.Y. In vitro induction of polyploidy in roots by colchicine treatment to increase biomass and ginsenoside biosynthesis from adventitious roots of wild ginseng. J. Pharmacogn. Nat. Prod. 2016, 2, 76.

82. Tang, Z.Q.; Chen, D.L.; Song, Z.J.; He, Y.C.; Cai, D.T. In vitro induction and identification of tetraploid plants of Paulownia tomentosa. Plant Cell Tissue Organ Cult. 2010, 102, 213-220. [CrossRef]

83. Divya, U.K.; Kumari, S.S. Development of In vitro Tetraploid Plants of Hevea brasiliensis. Int. J. Plant Soil Sci. 2019, $28,1-12$. [CrossRef]

84. Murashige, T.; Nakano, R. Tissue culture as a potential tool in obtaining polyploidy plants. J. Hered. 1966, 57, 115-118. [CrossRef]

85. Heinz, D.J.; Mee, G.W.P. Colchicine-Induced Polyploids from Cell Suspension Cultures of Sugarcane. Crop Sci. 1970, 10, 696-699. [CrossRef]

86. Hamada, K.; Inoue, M.; Tanaka, A.; Watanabe, H. Potato Virus Y-resistance in the progeny of haploid mutants obtained by the culture of Nicotiana tabacum L. anthers exposed to ion beams. Plant Biotechnol. 2001, 18, 251-257. [CrossRef]

87. He, P.; Li, L.; Cheng, L.; Wang, H.; Chang, Y. Variation in ploidy level and morphological traits in the progeny of the triploid apple variety Jonagold. Czech J. Genet. Plant Breed. 2018, 54, 135-142. 
88. Roy, A.T.; Leggett, G.; Koutoulis, A. In vitro tetraploid induction and generation of tetraploids from mixoploids in hop (Humulus lupulus L.). Plant Cell Rep. 2001, 20, 489-495. [CrossRef]

89. Omidbaigi, R.; Mirzaeea, M.; Hassani, M.E.; Sedghi-Moghadam, M. Induction and identification of polyploidy in basil (Ocimum basilicum L.) medicinal plant by colchicine treatment. Int. J. Plant Prod. 2010, 4, 87-98. [CrossRef]

90. Ghotbi Ravandi, E.G.; Rezanejad, F.; Zolala, J.; Dehghan, E. The effects of chromosome- doubling on selected morphological and phytochemical characteristics of Cichorium intybus L. J. Hortic. Sci. Biotechnol. 2013, 88, 701-709. [CrossRef]

91. Gantait, S.; Mukherjee, E. Induced autopolyploidy-A promising approach for enhanced biosynthesis of plant secondary metabolites: An insight. J. Genet. Eng. Biotechnol. 2021, 19, 4. [CrossRef] [PubMed]

92. Lattier, J.D.; Touchell, D.H.; Ranney, T.G.; Smith, J.C. Micropropagation and polyploid induction in Acer platanoides "Crimson Sentry". J. Environ. Hortic. 2013, 31, 246-252. [CrossRef]

93. Portela de Carvalho, J.F.R.; de Portela de Carvalho, C.R.; Otoni, W.C. In vitro induction of polyploidy in annatto (Bixa orellana). Plant Cell Tissue Organ Cult. 2005, 80, 69-75. [CrossRef]

94. Lavania, U.C. Polyploidy, body size, and opportunities for genetic enhancement and fixation of heterozygosity in plants. Nucleus 2013, 56, 1-6. [CrossRef]

95. Hannweg, K.; Visser, G.; de Jager, K.; Bertling, I. In vitro-induced polyploidy and its effect on horticultural characteristics, essential oil composition and bioactivity of Tetradenia riparia. S. Afr. J. Bot. 2016, 106, 186-191. [CrossRef]

96. Urwin, N.A. Generation and characterization of colchicine-induced polyploid Lavandula $\times$ intermedia. Euphytica 2014, 197, 331-339. [CrossRef]

97. te Beest, M.; Le Roux, J.J.; Richardson, D.M.; Brysting, A.K.; Suda, J.; Kubešová, M.; Pyšek, P. The more the better? The role of polyploidy in facilitating plant invasions. Ann. Bot. 2012, 109, 19-45. [CrossRef] [PubMed]

98. Levin, D.A. Polyploidy and novelty in flowering plants. Am. Nat. 1983, 122, 1-24. [CrossRef]

99. Yang, X.; Ye, C.Y.; Cheng, Z.-M.; Tschaplinski, T.J.; Wullschleger, S.D.; Yin, W.; Xia, Z.; Tuskan, G.A. Genomic aspects of research involving polyploid plants. Plant Cell Tissue Organ Cult. 2011, 104, 387-397. [CrossRef]

100. Gomes, S.S.L.; Saldanha, C.W.; Neves, C.S.; Trevizani, M.; Raposo, N.R.B.; Notini, M.M.; Santos, M.D.O.; Campos, J.M.S.; Otoni, W.C.; Viccini, L.F. Karyotype, genome size, and in vitro chromosome doubling of Pfaffia glomerata (Spreng.) Pedersen. Plant Cell Tissue Organ Cult. 2014, 118, 45-56. [CrossRef]

101. Mansouri, H.; Bagheri, M. Induction of Polyploidy and Its Effect on Cannabis sativa L. In Cannabis sativa L.: Botany and Biotechnology; Chandra, S., Lata, H., El Sohly, M., Eds.; Springer: Cham, Switzerland, 2017; pp. 365-383. [CrossRef]

102. Trojak-Goluch, A.; Skomra, U. Ploidy variation and agronomic performance of $F_{1}$ hybrids of tetraploid and diploid forms of Humulus lupulus L. Breed. Sci. 2020, 70, 176-182. [CrossRef]

103. Gantait, S.; Mandal, N.; Bhattacharyya, S.; Das, P.K. Induction and identification of tetraploids using in vitro colchicine treatment of Gerbera jamesonii Bolus cv. Sciella. Plant Cell Tissue Organ Cult. 2011, 106, 485-493. [CrossRef]

104. Abdoli, M.; Moieni, A.; Badi, H.N. Morphological, physiological, cytological and phytochemical studies in diploid and colchicineinduced tetraploid plants of Echinacea purpurea (L.). Acta Physiol. Plant. 2013, 35, 2075-2083. [CrossRef]

105. Noori, S.A.S.; Norouzi, M.; Karimzadeh, G.; Shirkool, K.; Niazian, M. Effect of colchicine-induced polyploidy on morphological characteristics and essential oil composition of ajowan (Trachyspermum ammi L.). Plant Cell Tissue Organ Cult. 2017, 130, 543-551. [CrossRef]

106. Imery, J.; Cequea, H. Colchicine-induce auto-tetraploid in Aloe vera L. Cytologia 2001, 66, 4006-4012. [CrossRef]

107. Xing, S.H.; Guo, X.B.; Wang, Q.; Pan, Q.F.; Tian, Y.S.; Liu, P.; Zhao, J.Y.; Wang, G.F.; Sun, X.F.; Tang, K.X. Induction and flow cytometry identification of tetraploids from seed-derived explants through colchicine treatments in Catharanthus roseus (L.) G. Don. J. Biomed. Biotechnol. 2011, 2011, 793198. [CrossRef]

108. Marzougui, N.; Boubaya, A.; Elfalleh, W.; Ferchichi, A.; Beji, M. Polyploidy induction in Trigonella foenum-graecum L. Morphological and chemical comparison between diploids and induced autotetraploids cultivars. Acta Bot. Gall. 2009, 156, 379-389. [CrossRef]

109. Paredes, T.M.; Viloria, M. Características morfológicas y producción de aloína de plantas poliploides de Aloe vera (L.) Burm F. (Asphodelaceae). Bioagro 2021, 33, 41-50. [CrossRef]

110. Lin, H.; Jian, M.; Liang, L.Y.; Pei, W.J.; Liu, X.Z.; Zhang, H.Y. Production of polyploids from cultured shoot tips of Eucalyptus globulus Labill by treatment with colchicine. Afr. J. Biotechnol. 2010, 9, 2252-2255.

111. Zhou, J.; Guo, F.; Fu, J.; Xiao, Y.; Wu, J. In vitro polyploid induction using colchicine for Zingiber Offcinale Roscoe cv. "Fengtou" ginger. Plant Cell Tissue Organ Cult. 2020, 142, 87-94. [CrossRef]

112. Dixit, V.; Chaudhary, B.R. Colchicine-induced tetraploidy in garlic (Allium sativum L.) and its effect on allicin concentration. J. Hortic. Sci. Biotechnol. 2014, 89, 585-591. [CrossRef]

113. Dabholkar, A.R. General Plant Breeding; Concept Publishing Company: New Delhi, India, 2006.

114. Le, K.-C.; Ho, T.-T.; Lee, J.-D.; Paek, K.-Y.; Park, S.-Y. Colchicine Mutagenesis from Long-term Cultured Adventitious Roots Increases Biomass and Ginsenoside Production in Wild Ginseng (Panax ginseng Mayer). Agronomy 2020, 10, 785. [CrossRef]

115. Xu, C.G.; Tang, T.X.; Chen, R.; Liang, C.H.; Liu, X.Y.; Wu, C.L.; Yang, Y.S.; Yang, D.P.; Wu, H. A comparative study of bioactive secondary metabolite production in diploid and tetraploid Echinacea Purpurea (L.) Moench. Plant Cell Tissue Organ Cult. 2014, 116, 323-332. [CrossRef]

116. Schwanitz, F. Die Zellgröße als Grundelement in Phylogenese und Ontogenese. Der Züchter 1953, 23, 17-44. [CrossRef] 
117. Li, Q.; Yang, Y.; Wu, H. In vitro segregation of tetraploid and octoploid plantlets from colchicine-induced ploidy chimeras in Echinacea purpurea L. Hort. Sci. 2016, 51, 549-557. [CrossRef]

118. Yue, Y.; Zhu, Y.; Fan, X.; Hou, X.; Zhao, C.; Zhang, S.; Wu, J. Generation of octoploid switchgrass in three cultivars by colchicine treatment. Ind. Crops Prod. 2017, 107, 20-21. [CrossRef]

119. Probasco, G.; Varnum, S.; Hysert, D. Millennium-a new hop variety. J. Am. Soc. Brew. Chem. 2006, 64, 155-157. [CrossRef]

120. Zhang, X.Y.; Hu, C.G.; Yao, J.L. Tetraploidization of diploid Dioscorea results in activation of the antioxidant defense system and increased heat tolerance. J. Plant Physiol. 2010, 167, 88-94. [CrossRef] [PubMed]

121. Trojak-Goluch, A.; Skomra, U. Breeding of triploid common hop cultivars (Humulus lupulus L.). Polish J. Agron. 2018, 34, 3-10. [CrossRef]

122. Lavania, U.C.; Srivastava, S.; Lavania, S.; Basu, S.; Misra, N.K.; Mukai, Y. Autopolyploidy differentially influences body size in plants, but facilitates enhanced accumulation of secondary metabolites, causing increased cytosine methylation. Plant J. 2012, 71, 539-549. [CrossRef] [PubMed]

123. Rüdiger, W. Vergleichend-anatomische Untersuchungen an diploiden und tetraploiden Sippen kleinzelliger und großzelliger Leinsorten. Der Züchter 1953, 23, 243-248. [CrossRef]

124. Corneillie, S.; De Storme, N.; Van Acker, R.; Fangel, J.; De Bruyne, M.; De Rycke, R.; Geelen, D.; Willats, W.G.T.; Vanholme, B.; Boerjana, W. Polyploidy Affects Plant Growth and Alters Cell Wall Composition. Plant Physiol. 2019, 179, 74-87. [CrossRef]

125. Lavania, U.C. Genomic and ploidy manipulation for enhanced production of phyto-pharmaceuticals. Plant Genet. Resour. 2005, 3, 170-177. [CrossRef]

126. Ghimire, B.K.; Seong, E.S.; Nguyen, T.X.; Yoo, J.H.; Yu, C.Y.; Kim, S.H.; Chung, I.M. Assessment of morphological and phytochemical attributes in triploidand hexaploid plants of the bioenergy crop Miscanthus $\times$ giganteus. Ind. Crop. Prod. 2016, 89, 231-243. [CrossRef]

127. Mishra, B.K.; Pathak, S.; Sharma, A.; Trivedi, P.K.; Shukla, S. Modulated gene expression in newly synthesized auto-tetraploid of Papaver somniferum L. S. Afr. J. Bot. 2010, 76, 447-452. [CrossRef]

128. Levy, M. Altered glycoflavone expression in induced autotetraploids of Phlox drummondii. Biochem. Syst. Ecol. 1976, 4, 249-254. [CrossRef]

129. Berkov, S.; Philipov, S. Alkaloid production in diploid and autotetraploid plants of Datura stramonium. Pharm. Biol. 2002, 40, 617-621. [CrossRef]

130. Kaensaksiri, T.; Soontornchainaksaeng, P.; Soonthornchareonnon, N.; Prathanturarug, S. In vitro induction of polyploidy in Centella asiatica (L.) urban. Plant Cell Tissue Organ Cult. 2011, 107, 187-194. [CrossRef]

131. Vavilov, N.I. The Origin, Variation, Immunity and Breeding of Cultivated Plants; Ronald Press: New York, NY, USA, 1951; Volume 13, pp. 1-366.

132. Hoffmann, W.; Mudra, A.; Plarre, W. Szczegółowa Hodowla Roślin; PWRL: Warszawa, Poland, 1979; pp. 549-592. ISBN 83-09-00063-4. (In Polish)

133. Gosztola, B.; Nemeth, E.; Sarosi, S.; Szabo, K.; Kozak, A. Compatrative evaluation of chamomile (Matricaria recutita L.) populations from different origin. Int. J. Hort. Sci. 2006, 12, 91-95.

134. Seidler-Łożykowska, K. Odmiany Roślin Zielarskich; IWNiRZ: Poznań, Poland, 2016; pp. 19-22. (In Polish)

135. Carvalho, C.R.; Clarindo, W.R.; Praca, M.M.; Araujo, F.S.; Carels, N. Genome size, base composition and karyotype of Jatropha curcas L. an important biofuel plant. Plant Sci. 2008, 174, 613-617. [CrossRef]

136. Kim, H.-E.; Han, J.-E.; Lee, H.; Kim, J.-H.; Kim, H.-H.; Lee, K.-Y.; Shin, J.-H.; Kim, H.-K.; Park, S.-Y. Tetraploidization Increases the Contents of Functional Metabolites in Cnidium officinale. Agronomy 2021, 11, 1561. [CrossRef]

137. Kamburova, V.S.; Salakhutdinov, I.B.; Shermatov, S.E.; Buriev, Z.T.; Abdurakhmonov, I.Y. Cotton as a Model for Polyploidy and Fiber Development Study; Intechopen: London, UK, 2021. [CrossRef]

138. Guan, X.; Song, Q.; Chen, J. Polyploidy and small RNA regulation of cotton fiber development. Trend Plant Sci. 2014, 19, 516-528. [CrossRef] [PubMed]

139. Renny-Byfield, S.; Wendel, J.F. Doubling down on genomes: Polyploidy and crop plants. Am. Bot. 2014, 101, 1711-1725. [CrossRef] [PubMed]

140. Einspahr, D.W. Production and utilisation of triploid hybrid aspen. Iowa State J. Res. 1984, 58, 401-409.

141. Baumeister, G. Beispiele der Polyploidie-Züchtung. AFZ 1980, 26, 340-343.

142. Zhu, Z.; Kang, X.Y.; Zhang, Z. Studies on selection of natural triploids of Populus tomentosa. Sci. Silvae Sin. 1998, $34,22-31$.

143. Stanton, B.J.; Neale, D.B.; Li, S. Populus Breeding: From the Classical to the Genomic Approach. In Genetics and Genomics of Populus. Plant Genetics and Genomics: Crops and Models; Jansson, S., Bhalerao, R., Groover, A., Eds.; Springer: New York, NY, USA, 2010; pp. 309-312. [CrossRef]

144. Ulrich, K.; Ewald, D. Breeding triploid aspen and poplar clones for biomass production. Silvae Genet. 2014, 63, 47-58. [CrossRef]

145. Xi, X.J.; Jiang, X.B.; Li, D.; Guo, L.Q.; Zhang, J.F.; Wei, Z.Z.; Li, B.L. Induction of $2 \mathrm{n}$ pollen by colchicine in Populus $x$ popularis and its triploids breeding. Silvae Genet. 2011, 60, 155-160. [CrossRef]

146. Wang, J.; Kang, X.Y.; Li, D.H.; Chen, H.W.; Zhang, P.D. Induction of diploid eggs with colchicine during embryo sac development in Populus. Silvae Genet. 2010, 59, 40-48. [CrossRef]

147. Li, Y.H.; Kang, X.Y.; Wang, S.D.; Zhang, Z.H.; Chen, H.W. Triploid induction in Populus alba x P. glandulosa by chromosome doubling of female gametes. Silvae Genet. 2008, 57, 37-40. [CrossRef] 
148. Lewis, R.S. Transfer of resistance to potato virus Y (PVY) from Nicotiana africana to Nicotiana tabacum; possible influence of tissue culture on the rate of introgression. Theor. Appl. Gen. 2005, 110, 678-687. [CrossRef] [PubMed]

149. Trojak-Goluch, A.; Berbeć, A. Meiosis and fertility in interspecific hybrids of Nicotiana tabacum L. $\times$ N. glauca Grah. and their derivatives. Plant Breed. 2007, 126, 201-206. [CrossRef]

150. Acquaah, T.C.; Pires, J.C.; Birchler, J.A.; Auger, D.L.; Chen, Z.J.; Lee, H.S.; Martienssen, R.A. Understanding mechanisms of novel gene expression in polyploids. Trends Genet. 2007, 19, 141-147.

151. Role of Polyploidy Breeding in Crop Improvement. Seminar Paper, Department of Genetics and Plant Breeding, Bangabandhu Sheikh Mujibur Rahman Agricultural University. 2018. Available online: https://bsmrau.edu.bd/seminar/wpcontent/uploads/ sites/318/2018/06/Tamanna-seminar.pdf (accessed on 15 October 2021).

152. Griffin, R.A.; Chi, N.Q.; Harbard, J.L.; Son, D.H.; Harwood, C.E.; Price, A.; Vuong, T.D.; Koutoulis, A.; Thinh, H.H. Breeding polyploid varieties of tropical acacias: Progress and prospects. South. For. A J. For. Sci. 2015, 77, 41-50. [CrossRef]

153. Koide, Y.; Kuniyoshi, D.; Kishima, Y. Fertile tetraploids: New resources for future rice breeding? Front. Plant Sci. $2020,11,1231$. [CrossRef]

154. Kosakowska, O. Intrapopulation variability of flavonoid content in roots of Baikal skullcap (Scutellaria baicalensis Georgi). Herba Pol. 2017, 63, 20-31. [CrossRef]

155. Madani, H.; Escrich, A.; Hosseini, B.; Sanchez-Muñoz, R.; Khojasteh, A.; Palazon, J. Effect of polyploidy induction on natural metabolite production in medicinal plants. Biomolecules 2021, 1, 899. [CrossRef] 